\title{
Spent Fuel Behavior Under Abnormal Thermal Transients During Dry Storage
}

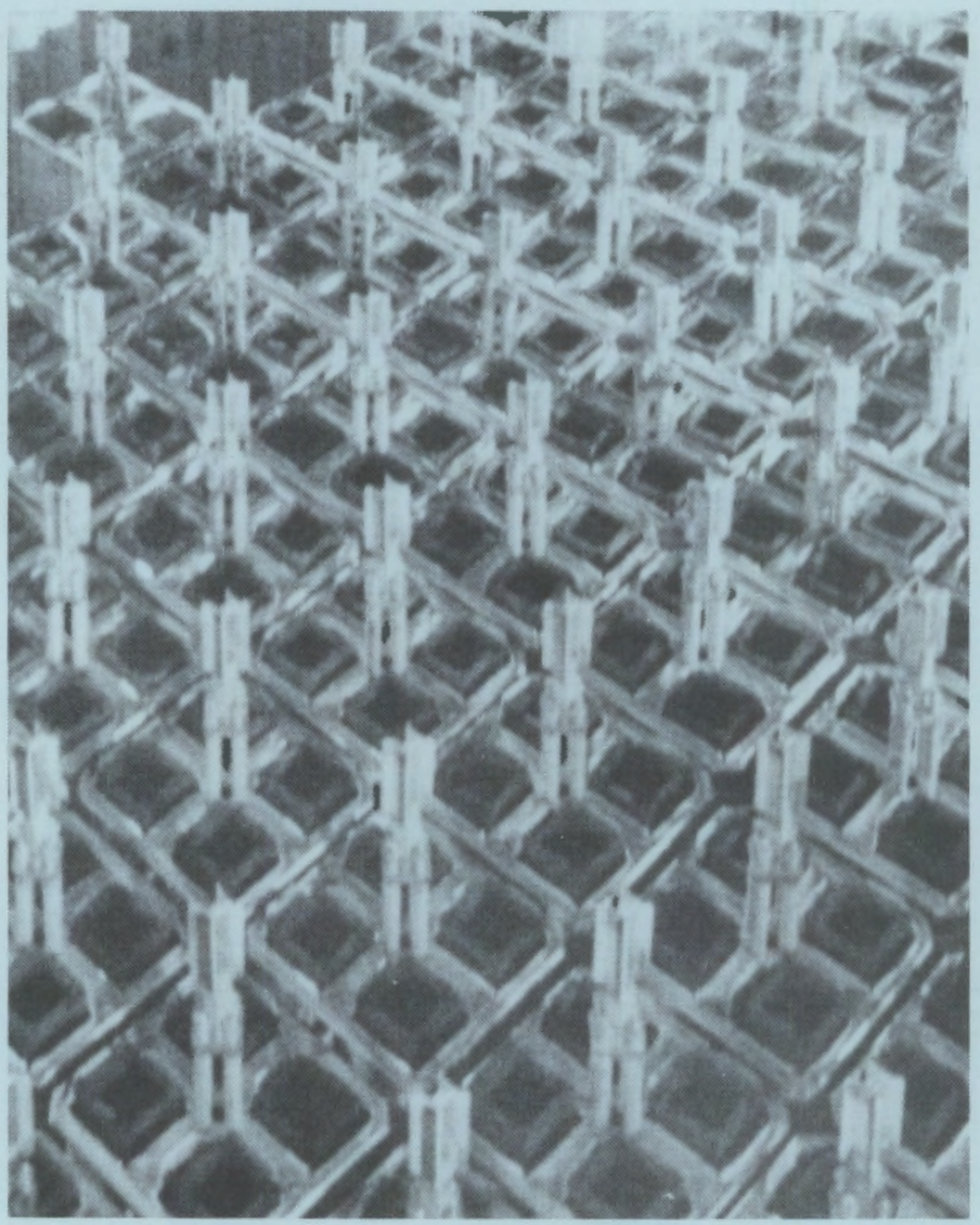

January 1986

Prepared by Battelle Columbus Laboratories for Pacific Northwest Laboratory under Contract DE-AC06-76RLO 1830 with the U.S. Department of Energy

Pacific Northwest Laboratory Operated for the U.S. Department of Energy by Battelle Memorial Institute 


\title{
DISCLAIMER
}

This report was prepared as an account of work sponsored by an agency of the United States Government. Neither the United States Government nor any agency thereof, nor any of their employees, makes any warranty, express or implied, or assumes any legal liability or responsibility for the accuracy, completeness, or usefulness of any information, apparatus, product, or process disclosed, or represents that its use would not infringe privately owned rights. Reference herein to any specific commercial product, process, or service by trade name, trademark, manufacturer, or otherwise, does not necessarily constitute or imply its endorsement, recommendation, or favoring by the United States Government or any agency thereof. The views and opinions of authors expressed herein do not necessarily state or reflect those of the United States Government or any agency thereof.

\author{
PACIFIC NORTHWEST LABORATORY \\ operated by \\ BATTELLE \\ for the \\ UNITED STATES DEPARTMENT OF ENERGY \\ under Contract DE-AC06-76RLO 1830
}

\begin{tabular}{|c|c|}
\hline \multirow{2}{*}{\multicolumn{2}{|c|}{ Printed in the United States of America }} \\
\hline & \\
\hline \multicolumn{2}{|c|}{$\begin{array}{l}\text { Available from } \\
\text { National Technical Information Service }\end{array}$} \\
\hline \multicolumn{2}{|c|}{$\begin{array}{l}\text { National Technical information Service } \\
\text { United States Department of Commerce }\end{array}$} \\
\hline \multicolumn{2}{|c|}{$\begin{array}{c}5285 \text { Port Royal Road } \\
\text { Springfield, Virginia } 22161\end{array}$} \\
\hline \multicolumn{2}{|c|}{ Springfield, Virginia 22161} \\
\hline \multirow{2}{*}{\multicolumn{2}{|c|}{$\begin{array}{l}\text { NTIS Price Codes } \\
\text { Microfiche A01 }\end{array}$}} \\
\hline & \\
\hline \multicolumn{2}{|c|}{ Printed Copy } \\
\hline Pages & $\begin{array}{l}\text { Price } \\
\text { Codes }\end{array}$ \\
\hline & \\
\hline $001-025$ & A02 \\
\hline 026-050 & $\mathrm{A03}$ \\
\hline $051-075$ & A04 \\
\hline $076-100$ & A05 \\
\hline $101-125$ & $A 06$ \\
\hline $126-150$ & A07 \\
\hline $151-175$ & $\mathrm{~A} 08$ \\
\hline $176-200$ & A09 \\
\hline $201-225$ & A010 \\
\hline $226-250$ & A011 \\
\hline $251-275$ & A012 \\
\hline $276-300$ & A013 \\
\hline
\end{tabular}


SPENT FUEL BEHAVIOR UNDER ABNORMAL THERMAL TRANSIENTS DURING DRY STORAGE

\section{Stahl}

M. P. Landow

R. J. Burian

V. Pasupathi

Battelle Columbus Laboratories

Columbus, Ohio 43201

E. R. Gilbert, PNL Program Manager

January 1986

Prepared by Battelle Columbus Laboratories for Pacific Northwest Laboratory under Contract DE-ACD6-76RLO 1830 with the U.S. Department of Energy

Pacific Northwest Laboratory Richland, Washington 99352 


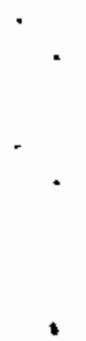

, 


\section{ACKNOWLEOGMENTS}

The work reported in this document was sponsored by the Commercial Spent Fuel Management Program office at Pacific Northwest Laboratory. The authors are indebted to the staff of the Battelle Columbus Laboratories hot cell facility, in particular A. Parsons and M. Berchtold. Thanks are also due to A. Plumer for setting up and running the computer codes. Consultations regarding test conditions were provided by $A_{\text {. }} B$. Johnson, Jr., and R. J. Guenther, Pacific Northwest Laboratory. 


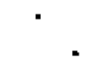


SUMMARY

Dry cask storage is being developed in the United States because utility spent fuel space is being depleted and spent fuel must be stored until repository disposal is available. The casks used for dry storage must be able to safely reject large heat loads to the environment. This study was performed to determine the effects of abnormally high temperatures on spent fuel behavior. The results of this study are applicable to safety analyses and evaluations of fuel conditions following a postulated abnormal heating event during dry storage.

Prior to testing, calculations using the CIRFI3 code were used to determine the steady-state fuel and cask component temperatures. The TRUMP code was used to determine transient heating rates under postulated abnormal events during which convection cooling of the cask surfaces was obstructed by a debris bed covering the cask. The peak rate of temperature rise during the first $6 \mathrm{~h}$ was calculated to be $\sim 15^{\circ} \mathrm{C} / \mathrm{h}$, followed by a rate of $\sim 1^{\circ} \mathrm{C} / \mathrm{h}$.

A Turkey Point spent fuel rod segment was heated to $-800^{\circ} \mathrm{C}$. The segment deformed uniformly with an average strain of $17 \%$ at failure and a local strain of $60 \%$. Pretest characterization of the spent fuel consisted of visual examination, profilometry, eddy-current examination, gamma scanning, fission gas collection, void volume measurement, fission gas analysis, hydrogen analysis of the cladding, burnup analysis, cladding metallography, and fuel ceramography. Post-test characterization showed that the failure was a pinhole cladding breach. The results of the tests showed that spent fuel temperatures in excess of $700^{\circ} \mathrm{C}$ are required to produce a cladding breach in fuel rods pressurized to 500 psig (3.45 MPa) under postulated abnormal thermal transient cask conditions. The pinhole cladding breach that developed would be too small to compromise the confinement of spent fuel particles during an abnormal event or after normal cooling conditions are restored. This behavior is similar to that found in other slow ramp tests with irradiated and nonirradiated rod sections and nonirradiated whole rods under conditions that bracketed postulated abnormal heating rates. This similarity is attributed to annealing of the irradiation-strengthened zircaloy cladding during heating. In both cases, the fatiure was a benign, ductile pinhole rupture. 
-

.

- 


\section{CONTENTS}

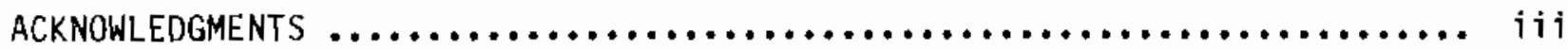

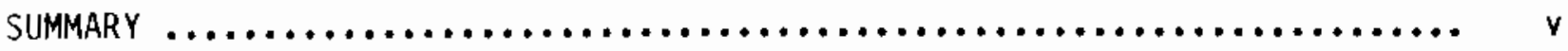

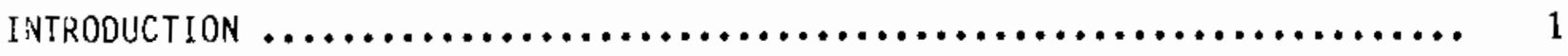

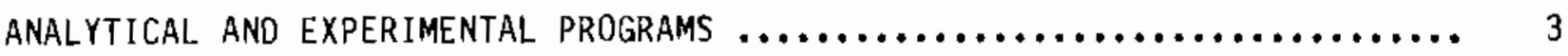

SPENT FUEL HEATING RATE ANALYSIS $\ldots \ldots \ldots \ldots \ldots \ldots \ldots \ldots \ldots \ldots \ldots, 3$

EXPERIMENTAL WORK $\ldots \ldots \ldots \ldots \ldots \ldots \ldots \ldots \ldots \ldots \ldots \ldots \ldots \ldots \ldots \ldots \ldots, 7$

Pretest Fuel Rod Characterization $\ldots \ldots \ldots \ldots \ldots \ldots \ldots \ldots \ldots \ldots, 7$

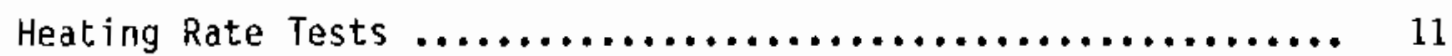

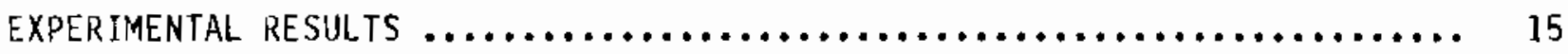

CONCLUSIONS $\ldots \ldots \ldots \ldots \ldots \ldots \ldots \ldots \ldots \ldots \ldots \ldots \ldots \ldots \ldots \ldots \ldots \ldots \ldots \ldots, 21$

REFERENCES $\ldots \ldots \ldots \ldots \ldots \ldots \ldots \ldots \ldots \ldots \ldots \ldots \ldots \ldots \ldots \ldots \ldots \ldots \ldots \ldots \ldots \ldots \ldots \ldots \ldots \ldots, 23$

APPENBIX - PRETEST CHARACTERIZATION DATA $\ldots \ldots \ldots \ldots \ldots \ldots \ldots \ldots \ldots \ldots \ldots \ldots \ldots \ldots \ldots \ldots \ldots$ 


\section{FIGURES}

1 Radial Section of Analytical Model for Two-Dimensional Analyses ..... 4

2 Transient Temperatures for Spent Fuel After Incident ............ 6

3 Transient Temperatures for Spent Fuel for Early Incident ......... 5

4 Spent Fuel Rod Segment Specimen Design with Welded Zircaloy End

Caps ............................................... 8

5 Mosaic of Specimen TP-D04-G9-13 $90 \mathrm{in.}$ from the Bottom

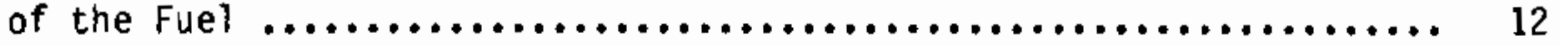

6 Fuel Microstructure of Rod TP-D04-G9 $65.5 \mathrm{in}$. from the Bottom

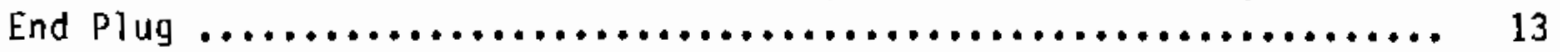

7 Fuel Microstructure of Rad TP-D04-G9 $90 \mathrm{in}$. from the Bottom

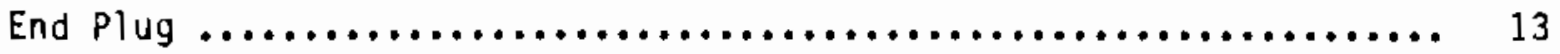

8 Failure Threshold Burst Test Apparatus ....................... 14

9 Time-Temperature-Pressure History for Welded Rod Segment

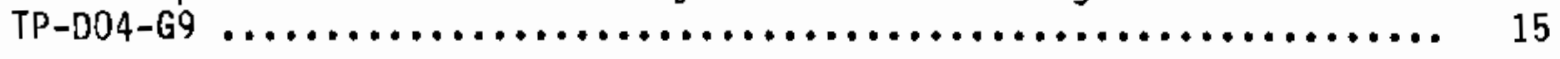

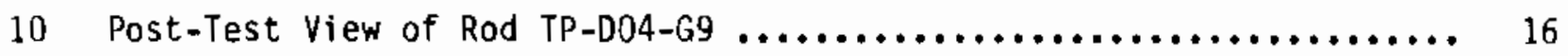

11 Faiture Temperature and Pressure Versus Heating Rate ............. 19

12 Cross-Sectional Views of Failure Location for Rod TP-D04-G9 ....... 20

TABLES

1 Results of Transient Heating Tests with PWR Fuel ............... 18

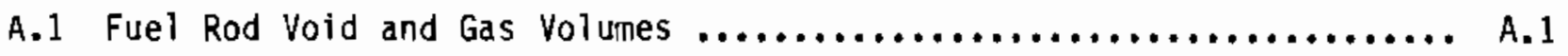

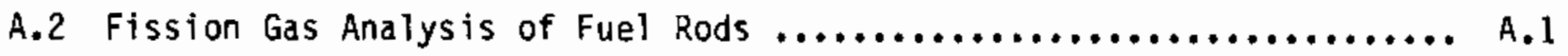

A.3 Hydrogen Analysis of Zircaloy-4 Cladding ................... A.2

A.4 0xide Thickness Measurements .................................. 
INTRODUCTION

Because spent fuel storage space in at-reactor pools is being depleted in she United States, alternatives to pool storage that could be added incrementally at a utility site are being assessed. One alternative, dry cask storage, takes advantage of the experience gained in dry storage of spent fuel (Johnson and Gilbert 1983). Casks used for dry storage must be capable of safely rejecting large heat loads to the environment. Heat is rejected to the environment largely by radiative and convective heat transfer from the body and finned surfaces of the cask. Thus, if heat transfer is impeded in any way, cask temperatures and fuel temperatures can increase. For example, convective heat transfer could be impeded by debris from a natural event such as an earthquake or tornado. No data are currently available to assess the rate of rise or the end point temperatures of the cask and fuel rods under these postulated conditions. Some experimental results under different conditions were obtained for the Sandia Transportation Technology Center by Battelle Columbus Laboratories (BCL) using an experimental arrangement similar to that used in the present study (Burian et al. 1985). These results provided some insight; however, the Sandia tests focused on characterization of the source term and not on fuel rod performance.

The work detailed in this report was sponsored by the Commercial Spent Fuel Management Program Office at Pacific Northwest Laboratory (PNL). (a) The objective of this work was to provide information on anticipated fuel rod behavior under postulated abnormal thermal transient conditions during dry storage. The study involved both analysis and experimentation. During the analysis, the rate of temperature rise was calculated as a function of heat loads and surface heat transfer coefficients for an assumed generic cask. Boundary conditions obtained from preliminary calculations and transient analyses provided the rate of fuel temperature increase during assumed abnormal events.

(a) Operated for the U.S. Department of Energy (DOE) by Battel le Memorial Institute under Contract DE-AC06-76RLO 1830. 
Using the TRUMP computer code, fuel temperatures were predicted to increase at $\sim 15^{\circ} \mathrm{C} / \mathrm{h}$ under the most severe conditions. In previous tests conducted on nonirradiated fuel rods (Guenther 1983), the behavior of the fuel rods was similar for rods heated at rates from 10 to $60^{\circ} \mathrm{C} / \mathrm{h}$. The experimental work discussed in this report was conducted at $55^{\circ} \mathrm{C} / \mathrm{h}$, which is within the range used by Guenther (1983) and thus would appear to apply for the most severe thermal transient case.

In the experimental work, the spent fuel rod segment was heated in an existing furnace at the BCL hot cell laboratory to determine the effects of abnormal transient heating on spent fuel. The pressurized-water reactor (PWR) fuel rods, which had a prototypic burnup of $\sim 30,000$ MWd/MTI, were from the Turkey point reactor. These rods had been previously characterized during the CLIMAX program conducted at BCL (Atkin 1981; Davis 1981). The characterization included visual examination, profilometry, eddy-current examination, gamma scanning, fission gas collection, void volume measurement, fission gas analysis, hydrogen andysis of the cladding, burnup analysis, cladding metallography, and fuel ceramography. The rod segment was also characterized after the test. The fuel rod segment was heated from $300^{\circ} \mathrm{C}$ to approximately $800^{\circ} \mathrm{C}$ at a rate of $55^{\circ} \mathrm{C} / \mathrm{h}$. The pressure and temperature were monitored continuously. The segment was heated to $300^{\circ} \mathrm{C}$ in less than $1 \mathrm{~h}$.

The objectives of the experimental activities were to determine the failure time, temperature, and pressure of spent PWR fuel using a 12-in.-long (30-cm-long) segment. The results allow the extension of failure predictions for PWR fuel rods under transient heating conditions from the few minutes associated with a loss-of-coolant accident (LOCA) (where data are avaiTable) to longer periods of several days that are more typical of abnormal cask events (where data are not availabie). These results for an irradiated fuel rod segment were compared with those obtained for nonirradiated full-iength fuel rods in a similar PNL program (Guenther 1983) and for nonirradiated and irradiated rod segments in the Sandia program (Burian et al. 1985). 
ANALYTICAL AND EXPERIMENTAL PROGRAMS

The analytical portion of the study was conducted to provide guidance in designing tests with appropriate heating rates. Transient analyses of spent "uel temperatures under assumed abnormal conditions identified heating rates - hat were used in the experimental studies. An assumed generic cask was used as the bas's for the model. Some preliminary work centered on pretest characterization of the fuel rods. Dnce the characterization was complete, the leating rate tests were initiated.

\section{SPENT FUEL HEATING RATE ANALYSIS}

Dry storage casks are typically right circular cylinders with the cavity opening at one end. In use, most casks are stored in the upright position. The fuel assemblies are held in the cavity in a basket and separated by divid. ers. If necessary, the dividers contain enough neutron poisons to assure a subcritical condition within the cask. The cylindrical walls and ends of the cask contain garma- and neutron-shielding materials.

The CIRF13 computer code was used for the steady-state fuel and cask component temperatures. This code provided a closed-form solution for cask component boundary temperatures and heat generation for given ambient and outer surface temperatures. The code was written for a horizontally oriented cask and included convective and radiative effects at the surface. It was modified to account for convective effects in the water $/ 50 \%$ glycol shield by adding a routine to calculate an effective heat transfer coefficient for the water $/ 50 \%$ jiycol annulus; the Lis correlation was used to calculate this coefficient itis 1966).

The thermal transient analyses were conducted using the TRUMP computer Jrogram (Edwards 1972). The two-dimensional analytical model (radial and axial) contained 37 nodes consisting of six materials. A radial section of the nodel is shown in Figure 1 . The ends of the cask were similarly modeled assuming only lead and stainless steel (SS) components (no neutron shield) with $5 \mathrm{in} .(15 \mathrm{~cm})$ of debris around the outside of the cask. The model assumed that the cask was horizontal. 


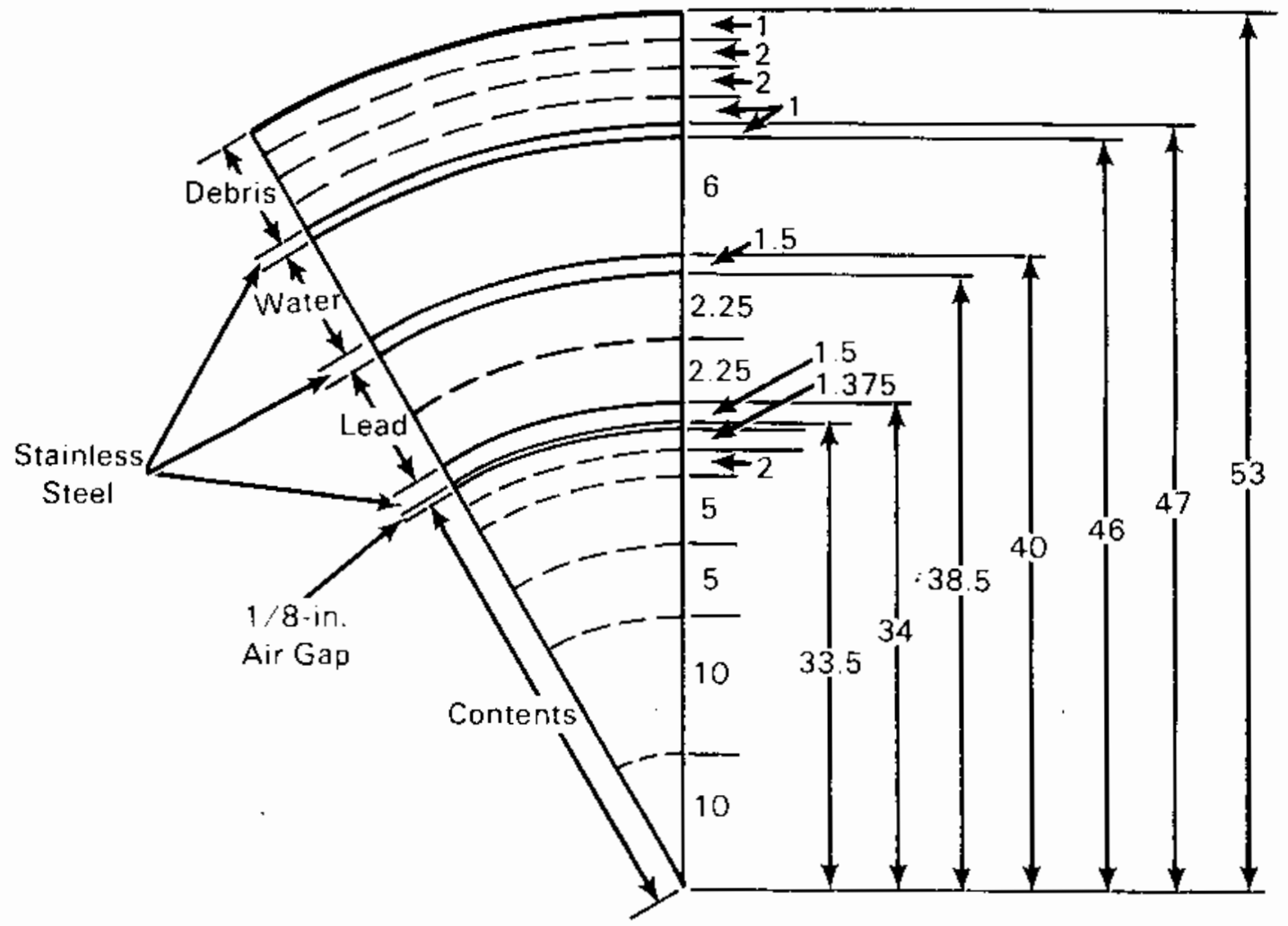

FIGURE 1. Radial Section of Analytical Model for Two-Dimensional Analyses (a)l dimensions in inches; $1 \mathrm{in,}=2.54 \mathrm{~cm}$ )

In this report, $250^{\circ} \mathrm{C}$ is used as the maximum temperature for safe operation in an unlimited air environment (Pasupathi and Stahl 1982). However, recent data and analys is have shown that $\mathrm{U}_{3} \mathrm{O}_{8}$ formation in breached spent fuel precludes storage in air at temperatures as high as $250^{\circ} \mathrm{C}$ (White et al. 1983; Einziger and Cook 1983; Gilbert et al. 1983; Gilbert, White, and Knox 1985). Instead, a temperature 1 imit of $380^{\circ} \mathrm{C}$ or higher in inert gas is recommended for dry storage of spent fuel (Johnson and Gilbert 1983). However, the test results presented in this report are still expected to remain applicable to storage at these higher temperatures.

Starting temperatures for the transient analyses were calculated for the model shown in Figure 1 with the debris removed and with heat being rejected to the environment directly from the neutron shield shell. Manual calculations using the heat transfer coefficient from the surface for the horizontal 
orientation verified that the temperature was within $5^{\circ} \mathrm{C}$ of that for the vertical (normal) orientation. Therefore, a separate model for the vertical orientation was not required.

The thermal properties used for the SS, lead, water, and air components were accepted handbook values. The thermal properties of the contents were determined either individually (for specific heat) or as a weighted average (for thermal conductivity) using the weights of the contents reported by Eggers (1982). The thermal properties of the debris were taken as those of a mixture of $80 \%$ concrete and $20 \%$ air.

The steady-state fuel cavity centerline temperature was calculated using the CIRFI3 inner cavity wall surface temperature and a heat transfer coefficient for homogenized cavity components (fuel, baskets, and air). It should be noted that the vertical versus the horizontal configuration (basket contact) and the composition of the baskets control the thermal conductivity coefficient. The composition and configuration of the baskets are the least welldefined factors. These preliminary calculations apply only to steady-state conditions. To determine the dependency of the temperature rise in the cask if the cask is covered with debris, more refined calculations were performed using the TRUMP code (Edwards 1972).

The temperatures calculated for the steady-state condition without debris were used as the starting temperatures for the transient analyses. The nodes representing the debris were added to the model and assigned an initial temperature of $21^{\circ} \mathrm{C}$. The calculated transient temperatures for spent fuel are presented in Figure 2. These results indicate that the maximum allowable temperature of the spent fuel $\left(250^{\circ} \mathrm{C}\right)$ was not reached until about $55 \mathrm{~h}$ for PWR elements $(24 \mathrm{~kW})$ and $110 \mathrm{~h}$ for BWR elements $(20 \mathrm{~kW})$. For these conditions, the rate of temperature rise was fairly slow $\left(\sim 1^{\circ} \mathrm{C} / \mathrm{h}\right)$.

The rate of temperature rise of the fuel cavity was determined for the 24-kW heat load case with and without debris for code calibration. For the worst case, in which the debris is present early in the approach to equilibrium, the rate of rise during the first $6 \mathrm{~h}$ was calculated to be $14.6^{\circ} \mathrm{C} / \mathrm{h}$ (Figure 3). This value decreased to less than $1^{\circ} \mathrm{C} / \mathrm{h}$ in $48 \mathrm{~h}$. Thus, the experimental range of 10 to $60^{\circ} \mathrm{C} / \mathrm{h}$ brackets the worst-case debris condition. 


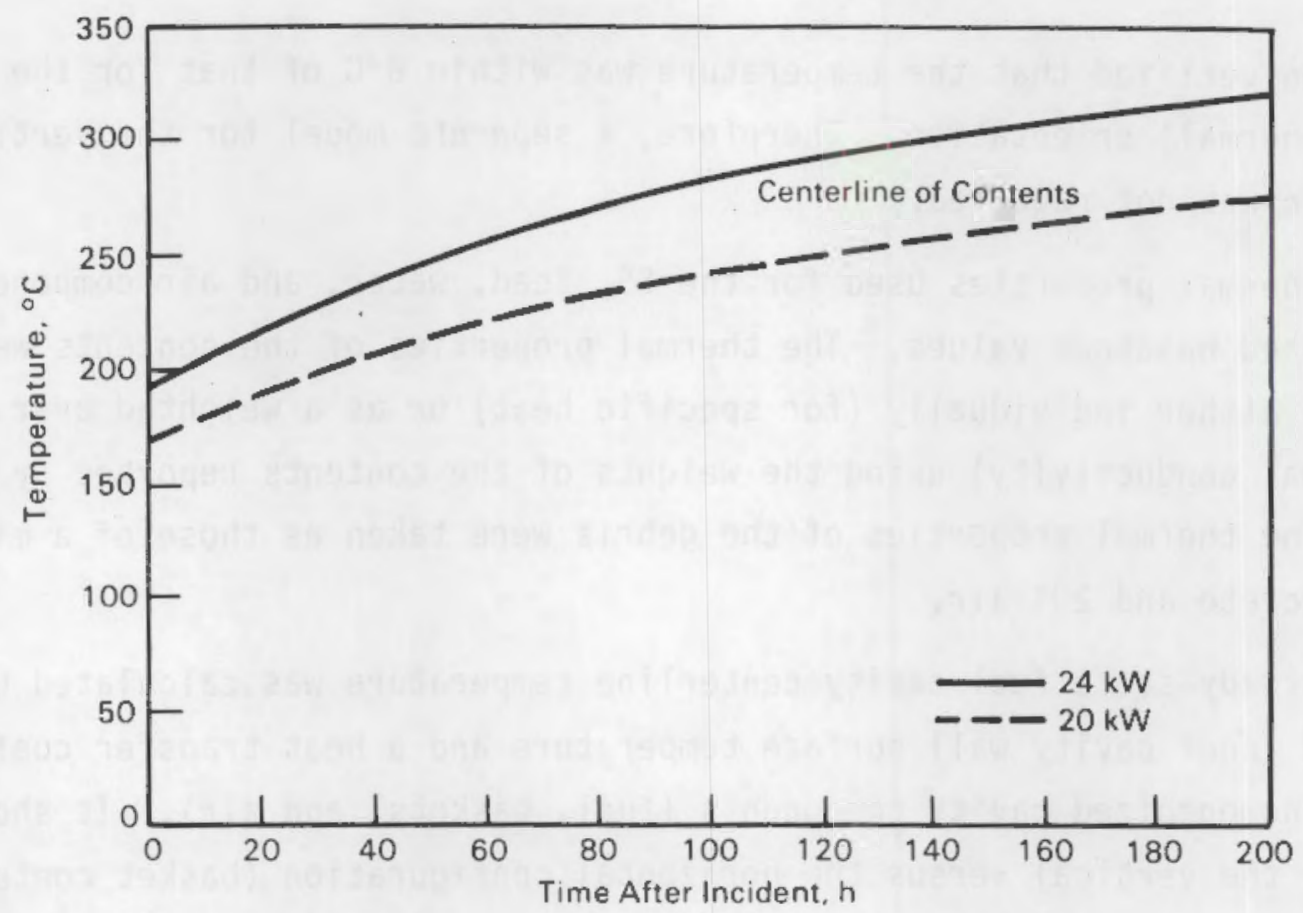

FIGURE 2. Transient Temperatures for Spent Fuel After Incident (incident occurs after the cask and its contents reach thermal equilibrium)

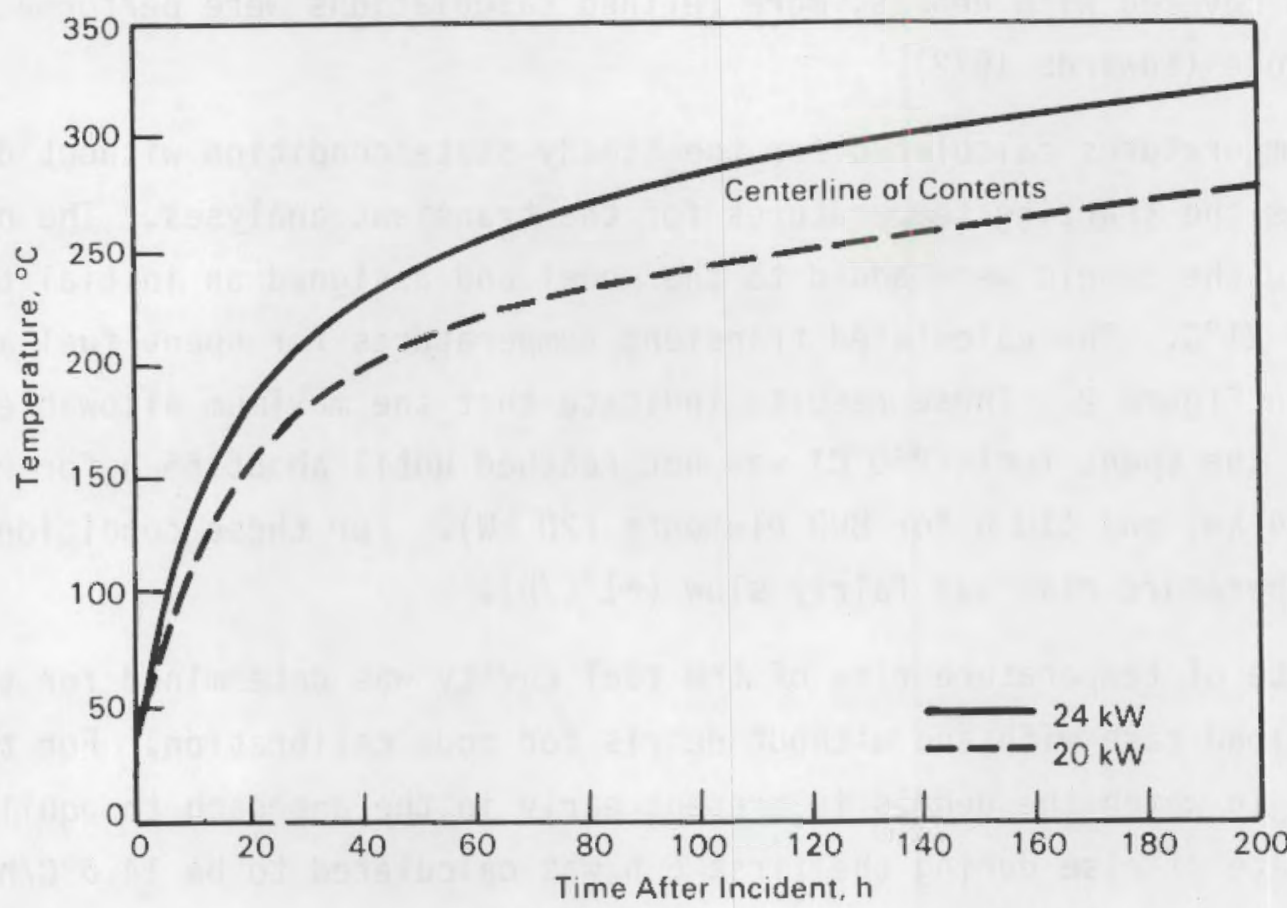

FIGURE 3. Transient Temperatures for Spent Fuel for Early Incident 
Because of the slow rates of temperature increase shown in Figures 2 and 3 , it appears that adequate time would be available for operator response to remove the blockage after a postulated abnormal thermal transient before a cladding breach could occur. The experimental range of 10 to $60^{\circ} \mathrm{C} / \mathrm{h}$ identified by this analytical study was also used to define the conditions for tests with nonirradiated fuel rods (Guenther 1983). The experimental work with nonirradiated spent fuel was performed to determine if those results could be applicable to irradiated fuel.

\section{EXPERIMENTAL WORK}

The pretest characterization data were largely taken from previous work performed on the Turkey Point spent fuel assemblies during the CLIMAX test program (Atkin 1981; Davis 1981). The rod segment was a 12-in.-long (30-cm-1ong) section taken from the region of uniform flux (Figure 4). A $1.7-\mathrm{cm}^{3}$ gas plenum was prepared at one end of the rod section to simulate the free gas volume-tototal volume ratio included within the cladding of a typical spent PWR fuel rod.

\section{Pretest Fuel Rod Characterization}

The pretest fuel rod characterization consisted of visual examination, profilometry, eddy-current examination, gamma scanning, fission gas collection, void volume measurement, fission gas analysis, hydrogen analysis of the cladding, burnup analysis, cladding metallography, and fuel ceramography.

\section{Visual Examination}

The fuel rods were examined visually through a stereo-optical viewing system and recorded with video equipment. Each rod was scanned at $6 \mathrm{X}$ magnification in three orientations $120^{\circ}$ apart. A measuring tape was placed next to the rod to identify the axial location.

The rod surfaces appeared to be generally covered with a shiny dark oxide. Shiny marks were visible along the rod where the oxide had been scratched off by handling with manipulators. Much of the rod surface was also covered with a patchy light crud layer from the reactor. However, this layer was too thin to be detected by profilometry or eddy-current examinations and did not appear to 


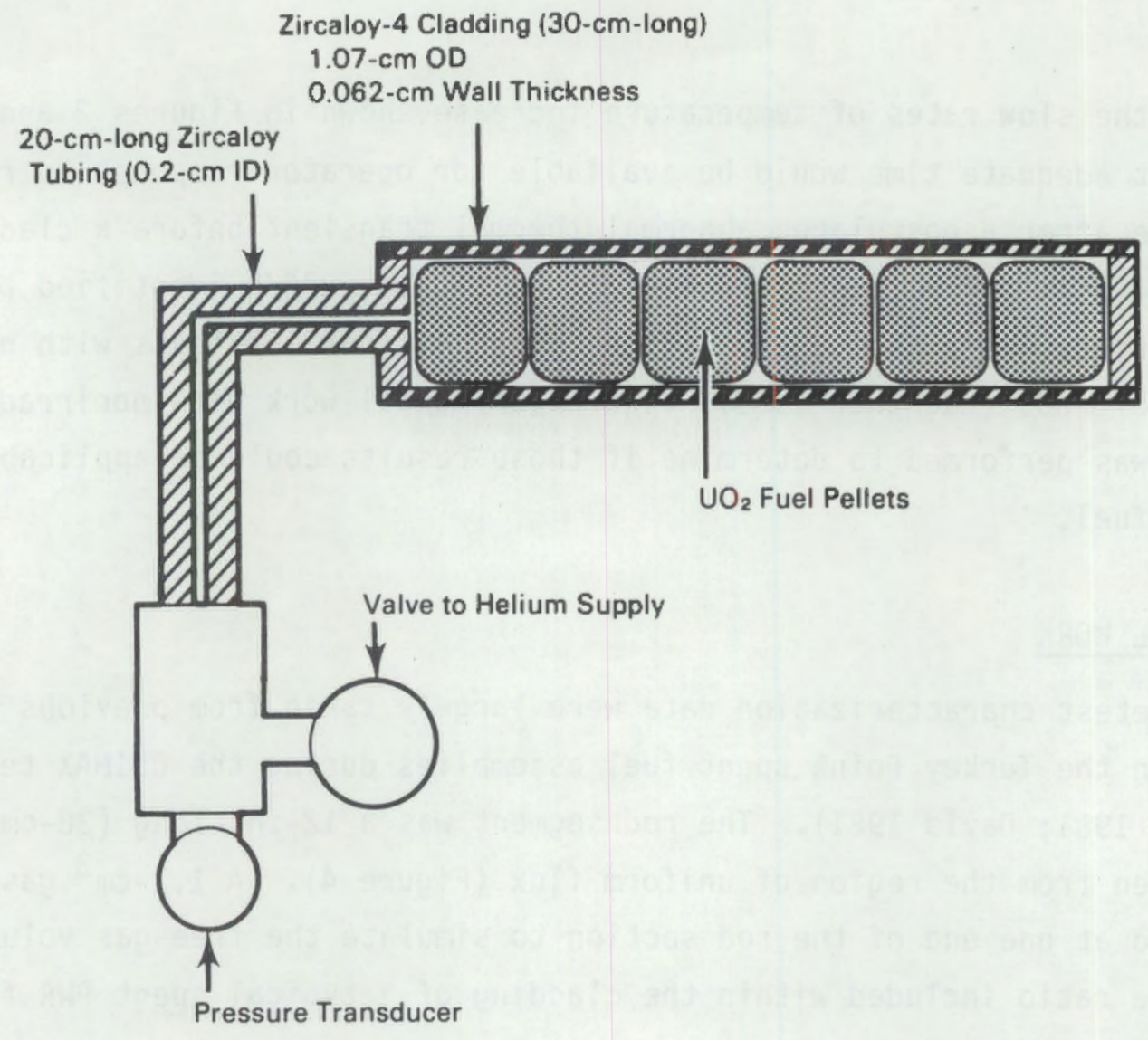

FIGURE 4. Spent Fuel Rod Segment Specimen Design with Welded Zircaloy End Caps

be significant. There was very little crud up to about 60 in. $(150 \mathrm{~cm})$ from the bottom of the rod. From 60 to $85 \mathrm{in}$. (150 to $220 \mathrm{~cm})$, the crud was patchy and appeared to be increasing in quantity. From $85 \mathrm{in} .(220 \mathrm{~cm})$ to the top of the rod, the crud layer covered the rod surface except for striations where the layer was scratched off when the rod was pulled through the grid spacers. The black oxide surface could be seen at these scratches. There was generally less of this light crud layer just above the grid spacer locations at 79 and 105 in. $(200$ and $270 \mathrm{~cm}$ ) from the bottom of the rod. The presence of surface crud did not appear to influence the test results.

\section{Profilometry}

Profilometry was performed to detect and characterize any local rod diameter anomalies and to determine the extent of ovality and cladding creepdown over the full length of the rod. The profilometer consisted of two linear 
variable differential transducers (LVDT) placed $180^{\circ}$ apart that moved axially along the fuel rod surface. The profilometer was calibrated with a standard cylindrical rod containing precisely machined steps of different diameters. The accuracy of the profilometer system and the precision of the measured mean diameter were both $0.0002 \mathrm{in.}(5 \mu \mathrm{m})$ ( $95 \%$ confidence). All rods exhibited typical creepdown in the fuel region that occurred during reactor service under coolant pressure. The extent of ridging at pellet interfaces, $<0.0005$ in. $(<13 \mu \mathrm{m})$, and the amount of ovality, $0.002 \mathrm{in} .(50 \mu \mathrm{m})$, were typical of spent fuel rods. The cladding creepdown reduced the gas volume surrounding the fuel pellets and enclosed by the cladding within the active fuel zone of the fuel rods.

\section{Eddy-Current Examination}

The fuel rods were scanned with an encircling coil eddy current to identify cladding discontinuities. No definite indications of cladding breaches were detected; indications of ridges were common, and some very small defects were observed.

\section{Gamma Scanning}

Gross and specific isotopic gamma activity along the length of the fuel rods was measured using the $\mathrm{BCL}$ hot cell gamma scanner to determine the condition of the fuel. Both gross and ${ }^{137} \mathrm{Cs}$ gamma scans exhibited typical flat chopped cosine curved profiles. The curves leveled off at $20 \mathrm{in}$. $(\sim 50 \mathrm{~cm})$ from either end of the fuel column. Gamma flux depressions were observed at nearly all pellet interfaces. No unusual spikes or "hot spots" were observed. An approximate $10 \%$ depression in the gamma activity was observed at each of the spacer grid locations. All gap widths were less than $0.08 \mathrm{in} .(0.20 \mathrm{~cm})$.

\section{Fission Gas Collection and Void Volume Measurement}

The BCL hot cell fission gas collection system was used to penetrate the selected fuel rod cladding and collect the gas. Internal void volumes and the amount of gas contained in the fuel rods are shown in the appendix (Table A.1). All rods contained approximately $700 \mathrm{~cm}^{3}$ of gas at standard temperature and pressure (STP) in an internal void volume of about $22 \mathrm{~cm}^{3}$. The two rods from Assembly DO4 contained slightly more gas in a slightly larger volume than the 
rods from Assembly D01. The pressures are slightly higher than the 480-psia (3.3-MPa) He prepressurization (Atkin 1981) and reflect the effects of reduced volume from cladding creepdown and the buildup of fission gases during irradiation.

\section{Fission Gas Analysis}

One vial of gas from each fuel rod was submitted for mass spectroscopy (Table A.2). All of the fuel rods contained essentially helium with less than $1 \%$ total krypton and xenon. The percentage of krypton and xenon released from the fuel was calculated to be about $0.21 \%$ based on the quantities of these gases generated at this burnup $\left(1670 \mathrm{~cm}^{3}\right)$ and the data in Tables A.1 and A.2. This low value is typical of PWR fuel rods.

\section{Hydrogen Analysis of the Cladding}

Samples of the Zircaloy-4 cladding were analyzed for hydrogen content by inert gas fusion (Table A.3). Each value in Table A.3 is the average of two or more analyses with the standard deviation. The values ranged from 40 to 90 ppm, which is typical of the hydrogen measured in PWR fuel rods. The values increased with distance from the bottom of the rod.

\section{Burnup Analysis}

Three samples from Assembly D01 (Rods G9, G10, and H9) and two from Assembly D04 (Rods $G 9$ and G10) were taken from about $66 \mathrm{in}$. $(170 \mathrm{~cm}$ ) from the bottom of the rod. Burnup values were consistent, ranging from 30,500 to $31,600 \mathrm{MWd} / \mathrm{MTU}$ (3.18 to 3.29 at.\%).

\section{Cladding Metallography}

Photomicrographs (100X) were taken at $90^{\circ}$ intervals around the sectioned samples of cladding to measure the cladding thickness. The magnification was calibrated by taking a series of 10 photomicrographs of the calibrated stage micrometer. The thickness ranged from 0.0239 to $0.0253 \mathrm{in}$. (607 to $643 \mathrm{~m})$ and averaged $0.02442 \mathrm{in}$. $(620 \mathrm{~mm})$, which is slightly higher than the nominal thickness of $0.0243 \mathrm{in} .(617 \mathrm{~mm})$.

Photomicrographs of the outside diameter of the cladding in the aspolished condition were taken at $500 x$ to evaluate the oxide layer (Table A.4). 
0xide thicknesses ranged from 2.79 to $15.75 \mu \mathrm{m}$ and tended to increase toward the top of the fuel rods. Some localized areas of the cladding showed evidence of oxide layer spallation. The difference in the thickness of the reoxidized layer is an indication of the time at irradiation temperature after the oxide layer spalled off.

Photomicrographs were also taken of the cladding after etching to bring out the structure of the hydrides. The hydrides appeared as long stringers in the cladding and were generally oriented circumferentially, although a few of the hydrides were oriented in a radial direction. Hydriding increased toward the top of the rod, which appears to correlate well with the hydrogen analysis data.

Fuel/cladding interaction was evident at various locations on the specimens. However, the inside diameter surfaces of the cladding showed only a few interaction zones.

\section{Fuel Ceramography}

The sectioned specimens were ground with progressively finer silicon carbide abrasive papers using water as a lubricant. This procedure was followed by polishing with a $1-\mu m$ alumina suspension in a $2 \%$ chromic acid solution. No unusual features were noted in the overall appearance of the fuel specimens in the as-polished condition. After this examination, a series of photomicrographs at $35 X$ that covered the entire specimen surface were taken and pieced together. A typical example is shown in Figure 5. The fuel specimens were then etched with a solution of $15 \% \mathrm{H}_{2} \mathrm{SO}_{4}(95 \%)$ and $85 \% \mathrm{H}_{2} \mathrm{O}_{2}(30 \%)$, and the fuel was examined at $100 \mathrm{x}$ and 500x. Fuel grain sizes tended to increase toward the center of the fuel rod. Figures 6 and 7 show fuel at the outer edge, midradius, and center of two sections from Rod TP-D04-G9. Intergranular porosity is present throughout the specimen, but it is most prevalent near the edge and much less prevalent near the center.

Heating Rate Tests

After leak checking, the welded rod segment was placed into the furnace and pressurized to $500 \mathrm{psig}(3.45 \mathrm{MPa})$ with helium to simulate the plenum pressure in spent fuel rods. The experimental arrangement is shown in figure 8. 


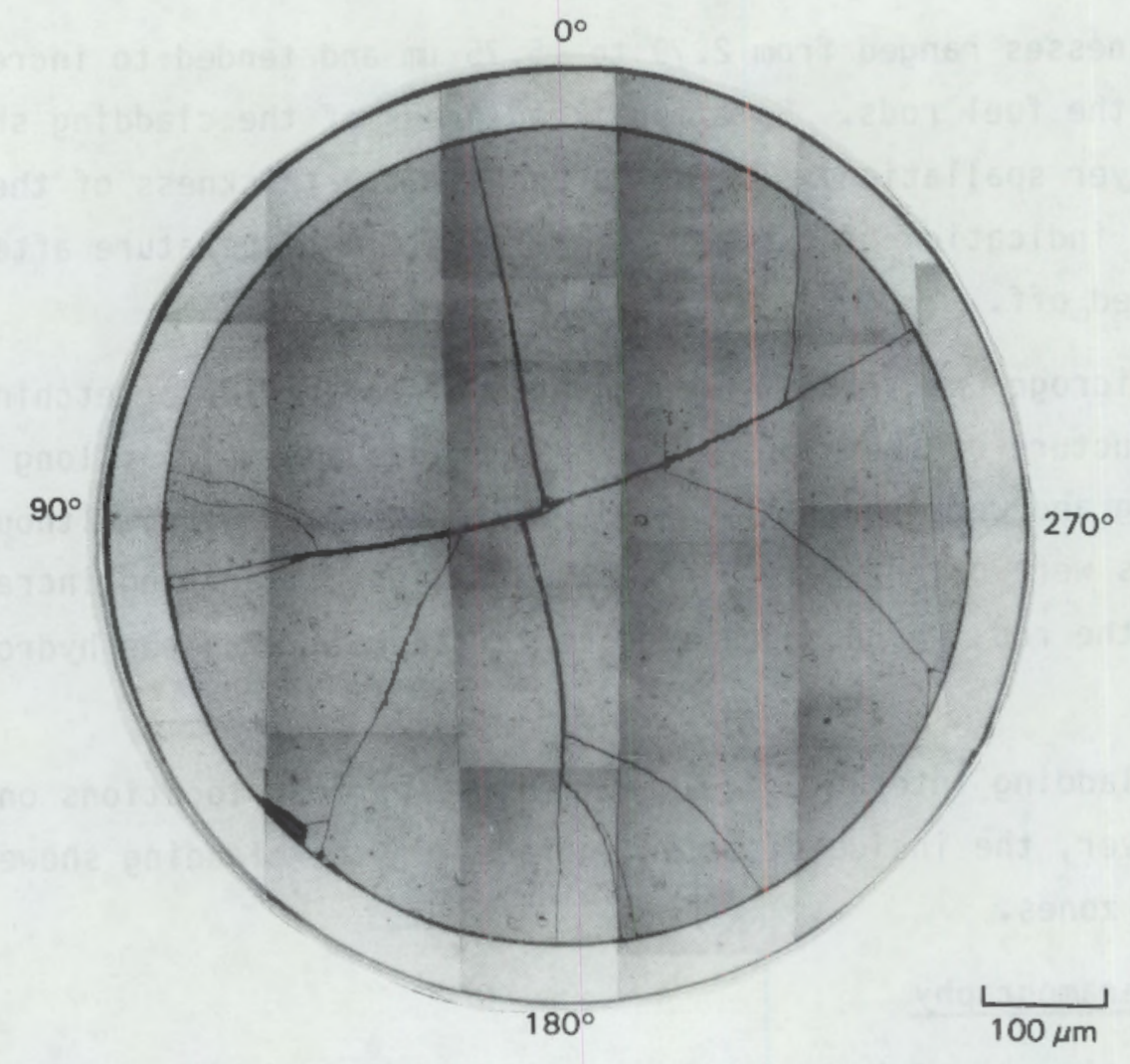

FIGURE 5. Mosaic of Specimen TP-D04-G9-13 $90 \mathrm{in.}(230 \mathrm{~cm})$ from the Bottom of the Fuel (Atkin 1981)

The preheater, furnace, filter system, and air pump are located inside the hot cell; the power supplies, controllers, and recorder are located outside.

The hot zone in the furnace was fairly flat (within $\pm 5^{\circ} \mathrm{C}$ ) so that the rod segment was uniformly heated along its length. The heating rate was $55^{\circ} \mathrm{C} / \mathrm{h}$, as determined from the analytical program. For this slow heating rate test, the initial heating rate was more rapid $\left(500^{\circ} \mathrm{C} / \mathrm{h}\right)$ until the rod reached $300^{\circ} \mathrm{C}$, at which time the rate was reduced to the test rate $\left(55^{\circ} \mathrm{C} / \mathrm{h}\right)$; this procedure saved considerable test time. It was determined that rapid heating to $300^{\circ} \mathrm{C}$ would not affect the fuel behavior during the test because tests at $325^{\circ} \mathrm{C}$ for times up to $2100 \mathrm{~h}$ showed little cladding strain (Einziger and Kohli 1984). The air flow through the system was set at $-6 \mathrm{~L} / \mathrm{min}$ at $1 \mathrm{~atm}$, and the preheater was used to prevent cool air from impinging on the system. 


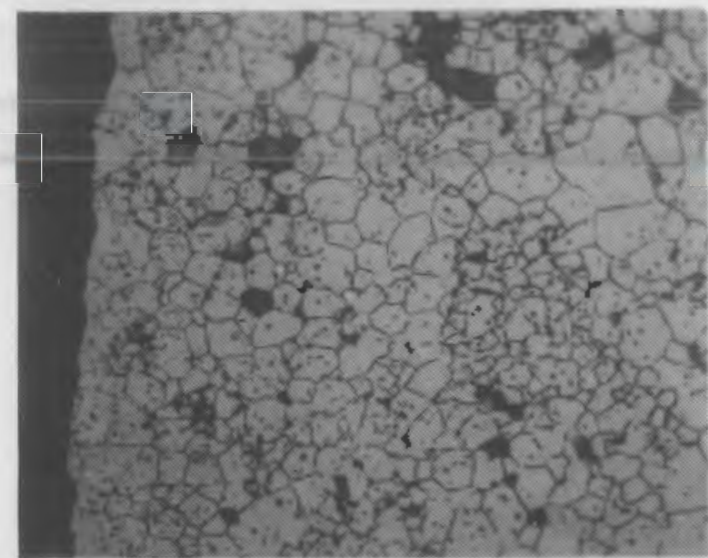

HC 49233

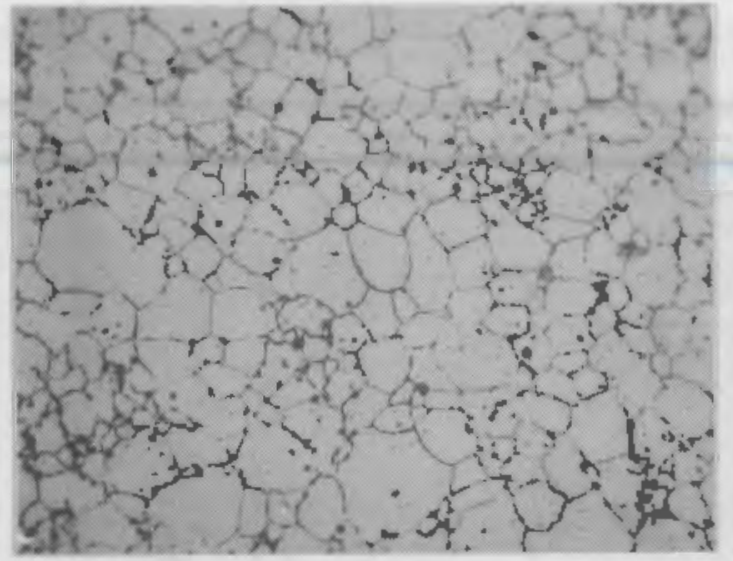

HC 49234

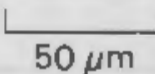

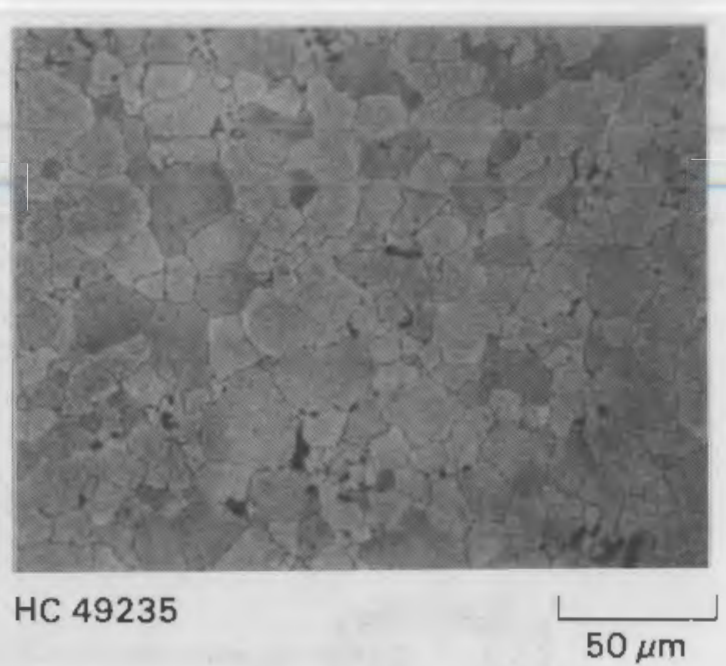

FIGURE 6. Fuel Microstructure of Rod TP-D04-G9 $65.5 \mathrm{in.}(165 \mathrm{~cm}$ ) from the Bottom End Plug

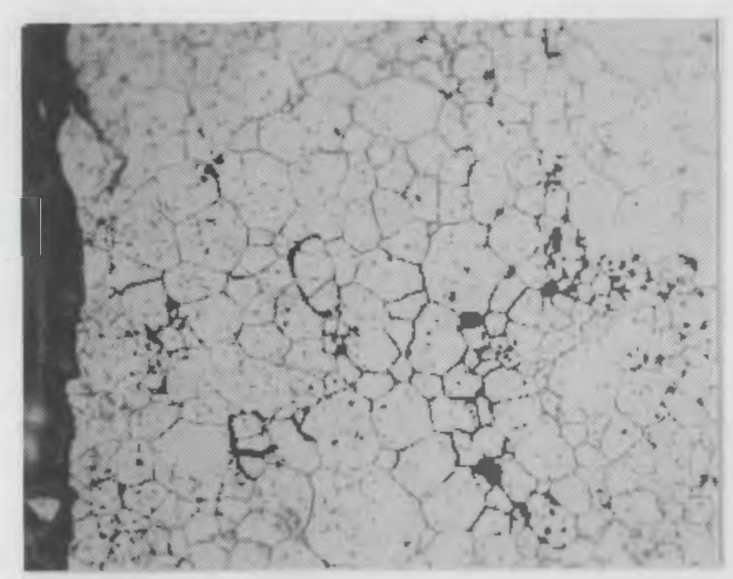

HC 49285

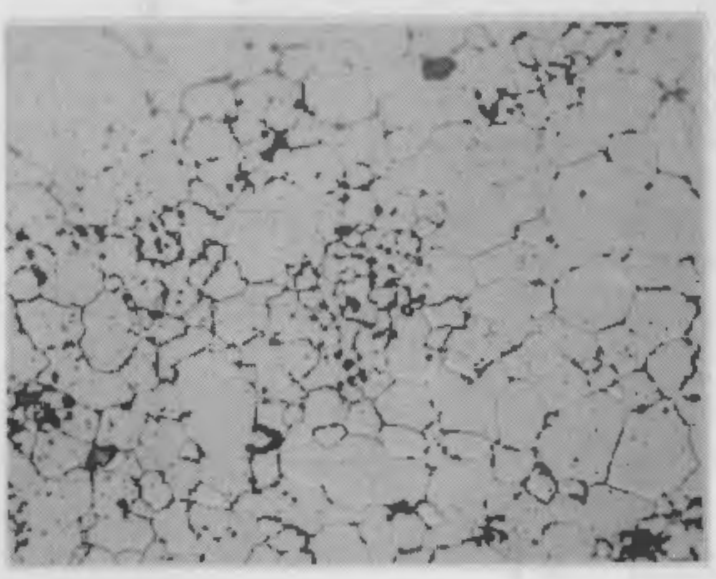

HC 49286

$50 \mu \mathrm{m}$

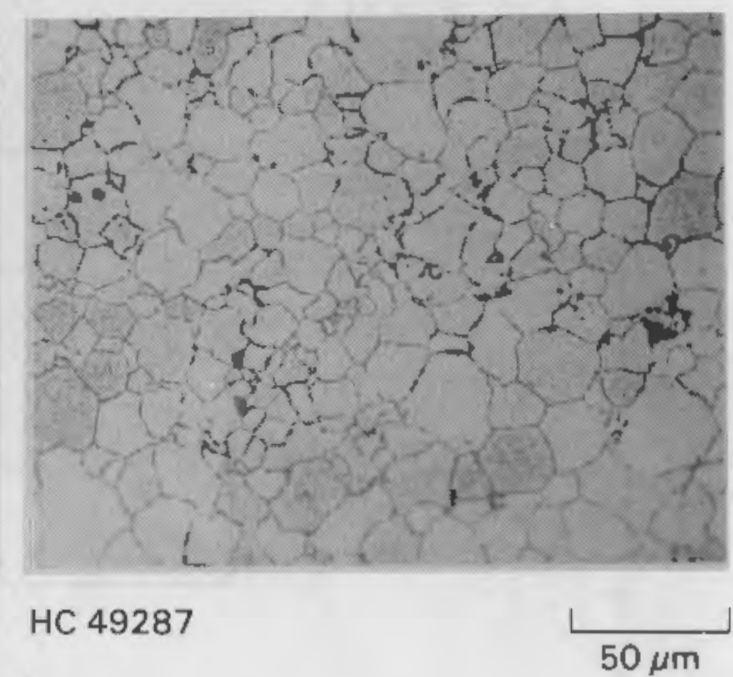

FIGURE 7. Fuel Microstructure of Rod TP-D04-G9 $90 \mathrm{in.}(230 \mathrm{~cm})$ from the Bottom End Plug 
In-Cell

Exhaust

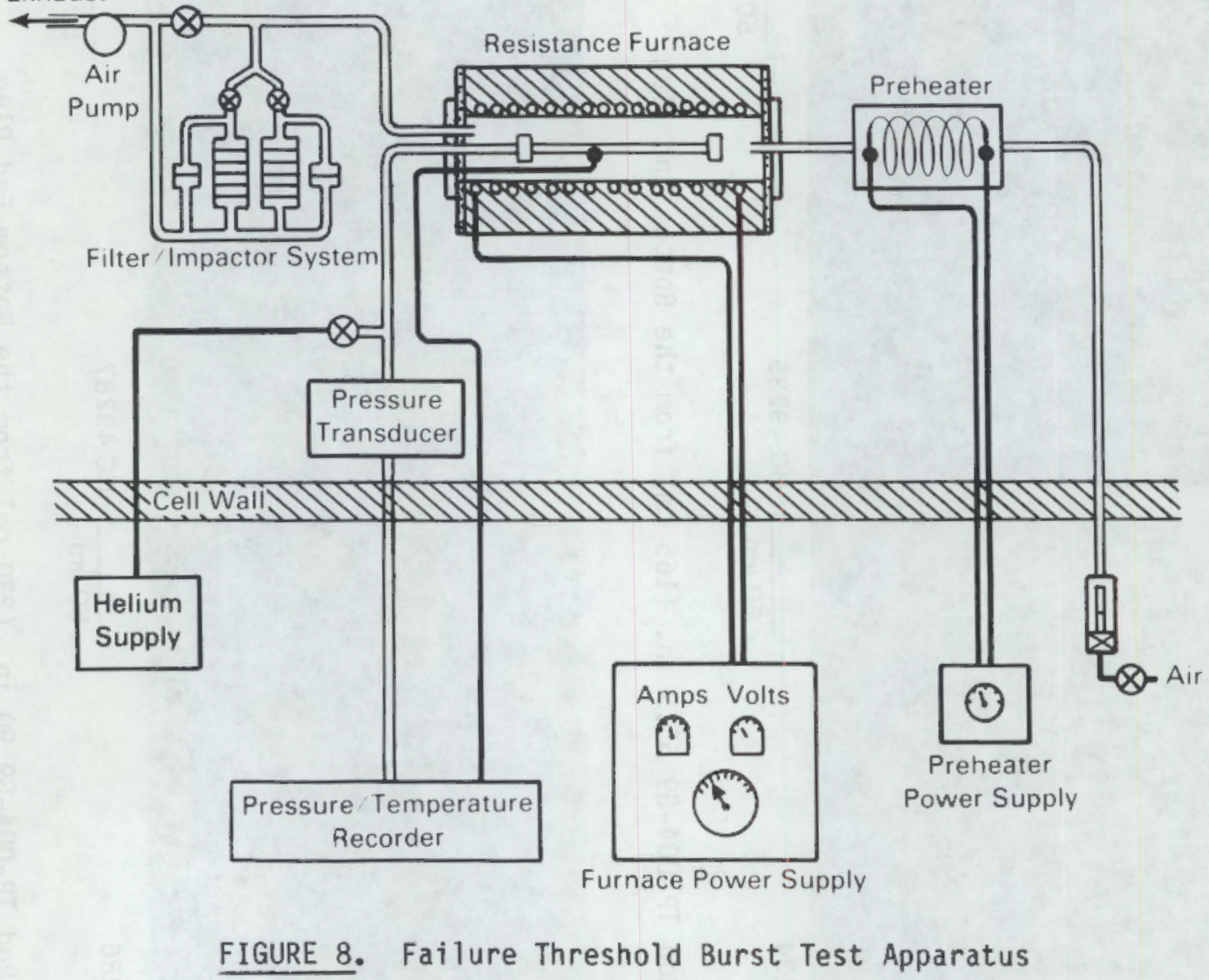




\section{EXPERIMENTAL RESULTS}

The time-temperature-pressure history for the test using welded end plugs is shown in Figure 9. The fuel probably behaved like a solid mandrel based on the high-density microstructures shown in Figures 5, 6, and 7. The initial heating rate was about $500^{\circ} \mathrm{C} / \mathrm{h}$; the final test heating rate was $55^{\circ} \mathrm{C} / \mathrm{h}$. The modest pressure rise during the latter portion of the test could be due to cladding deformation caused by recovery of irradiation strengthening. The test was terminated when the cladding of the rod segment failed. The rod segment and the pinhole failure are shown in Figure 10. This type of failure is similar to that observed in other. Turkey Point fuel segment tests performed at BCL for the Sandia Transportation Technology Center (Burian et al. 1985) and for tests on full-length nonirradiated rods performed at PNL (Guenther 1983). The

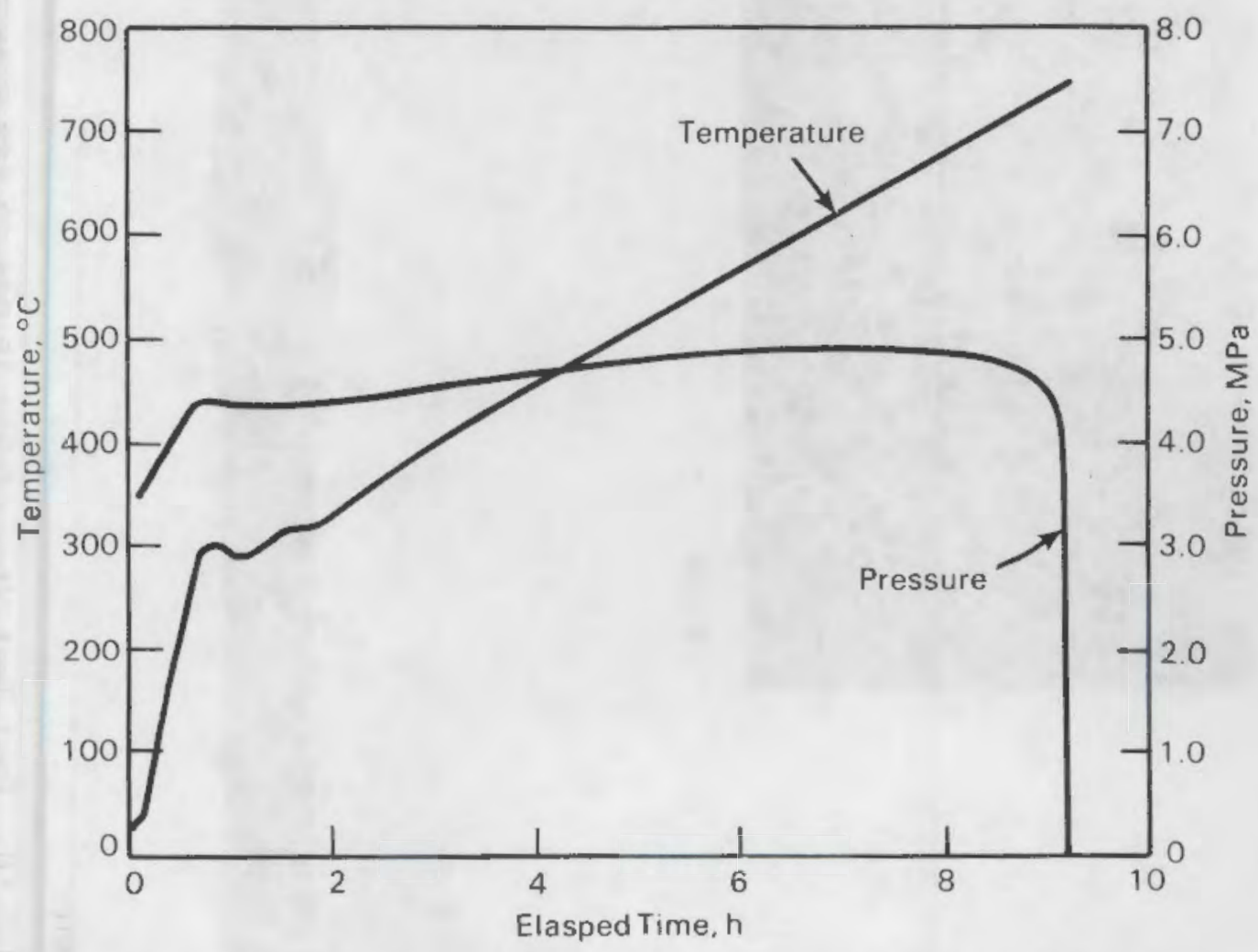

FIGURE 9. Time-Temperature-Pressure History for Welded Rod Segment TP-D04-G9 (22.5 to 34.25 in. above bottom of rod) 


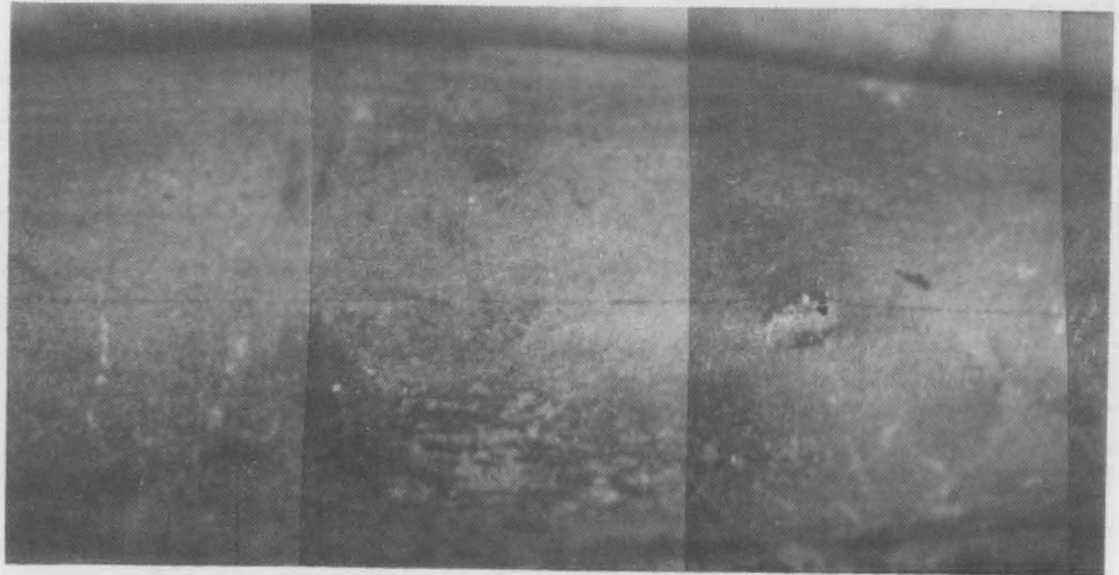

2056-59

$\sim 3 X$

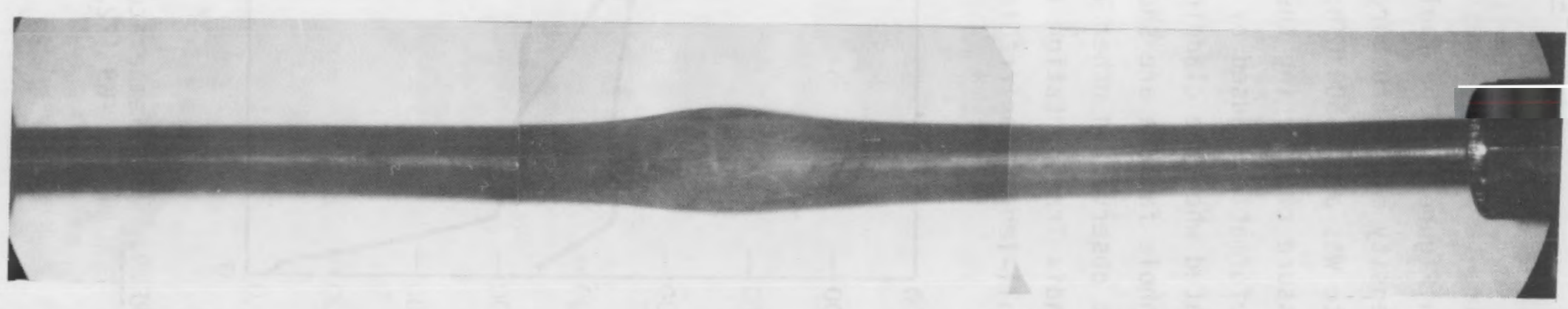

$2060 \cdot 62$

FIGURE 10. Post-Test View of Rod TP-D04-G9 (22.5 to $34.25 \mathrm{in}$. above bottom of rod; $55^{\circ} \mathrm{C} / \mathrm{h}$ heating rate) 
results of these transient heating tests are presented Table 1 . The tests designated IH were induction heated; the others were resistance heated; NR refers to the nonirradiated rod segment tests performed at BCL; the other designations refer to the tests performed at PNL.

Failure temperature and pressure data were plotted as a function of heating rate (Figure 11). The $\log$ of heating rate was used for convenience. The temperature and pressure data each fit reasonably well on one curve, indicating that whole rods and rod segments behaved similarly. In addition, the method of heating did not appear to have an effect. Failure pressure increased and failure temperature decreased with increasing heating rate, which is consistent with time- and temperature-dependent plastic yielding. Above $60^{\circ} \mathrm{C} / \mathrm{h}$, the failure temperature and pressure appeared to level out. Even under these latter conditions, the tube failed in a ductile manner, which permitted the potential pressure increase to be prevented by the increased volume resulting from uniform cladding deformation. In all cases, this uniform deformation resulted in local bulging and eventually very local cladding thinning and pinhole rupture. At much higher heating rates, there is inadequate time for plastic yielding and "fish-mouth" failures to occur (Lowry et al. 1981). Based on the fuel pellet microstructures shown in Figures 5, 6, and 7 , little fuel deformations is expected and the fuel would have little effect on the pressure-time behavior.

The maximum diametral strain was about $60 \%$, while the average diametral strain was about $17 \%$, which is consistent with results obtained for nonirradiated rods. A cross-sectional view of the cladding at the pinhole failure is shown in the upper photograph in Figure 12. The cladding is uniformly ballooned and thinned. A higher magnification view of the failure area is shown in the lower photograph in Figure 12. The edges of the failure region are thin and there is no evidence of mechanical instability. The failure apparently occurred from a surface depression that thinned and separated in a benign fashion. 
TABLE 1. Results of Transient Heating Tests with PWR Fuel(a)

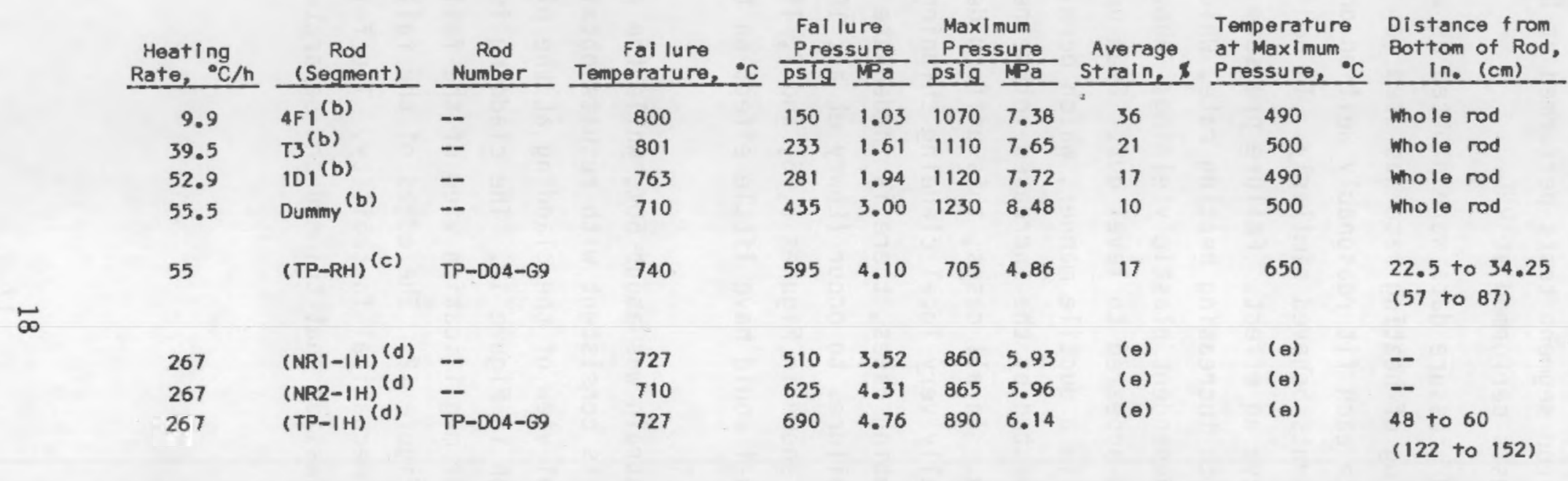

(a) Zi rcaloy-4 cladding; Initlal pressure was $500 \mathrm{psig}(3.45 \mathrm{MPa}$.

(b) Guenther (1983).

(c) TP - Turkey Polnt; RH - resistance heated; IH - Induction heated; NR - noni rrodiated.

(d) Burian et al. (1985).

(e) Not measured. 


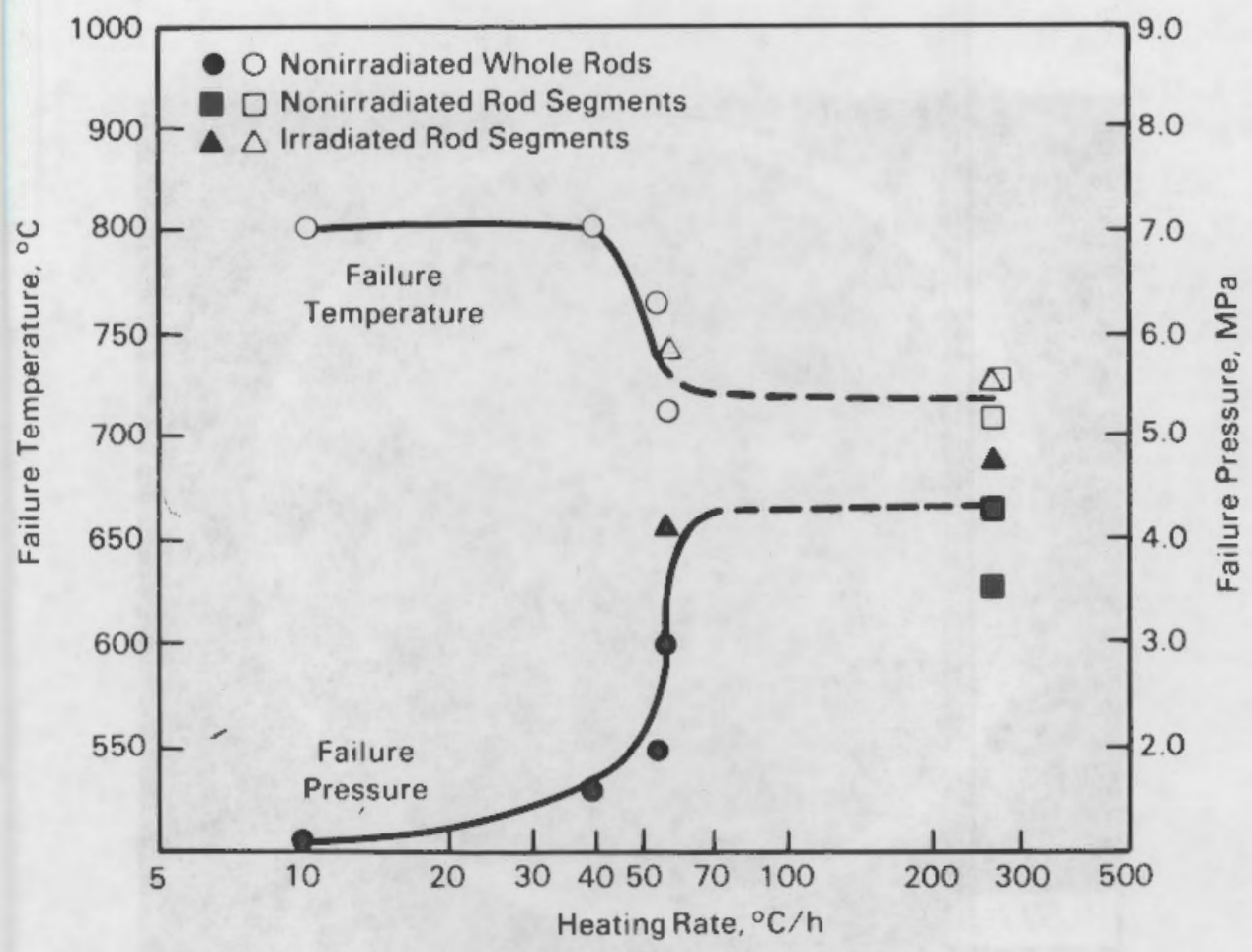

FIGURE 11. Failure Temperature and Pressure Versus Heating Rate 

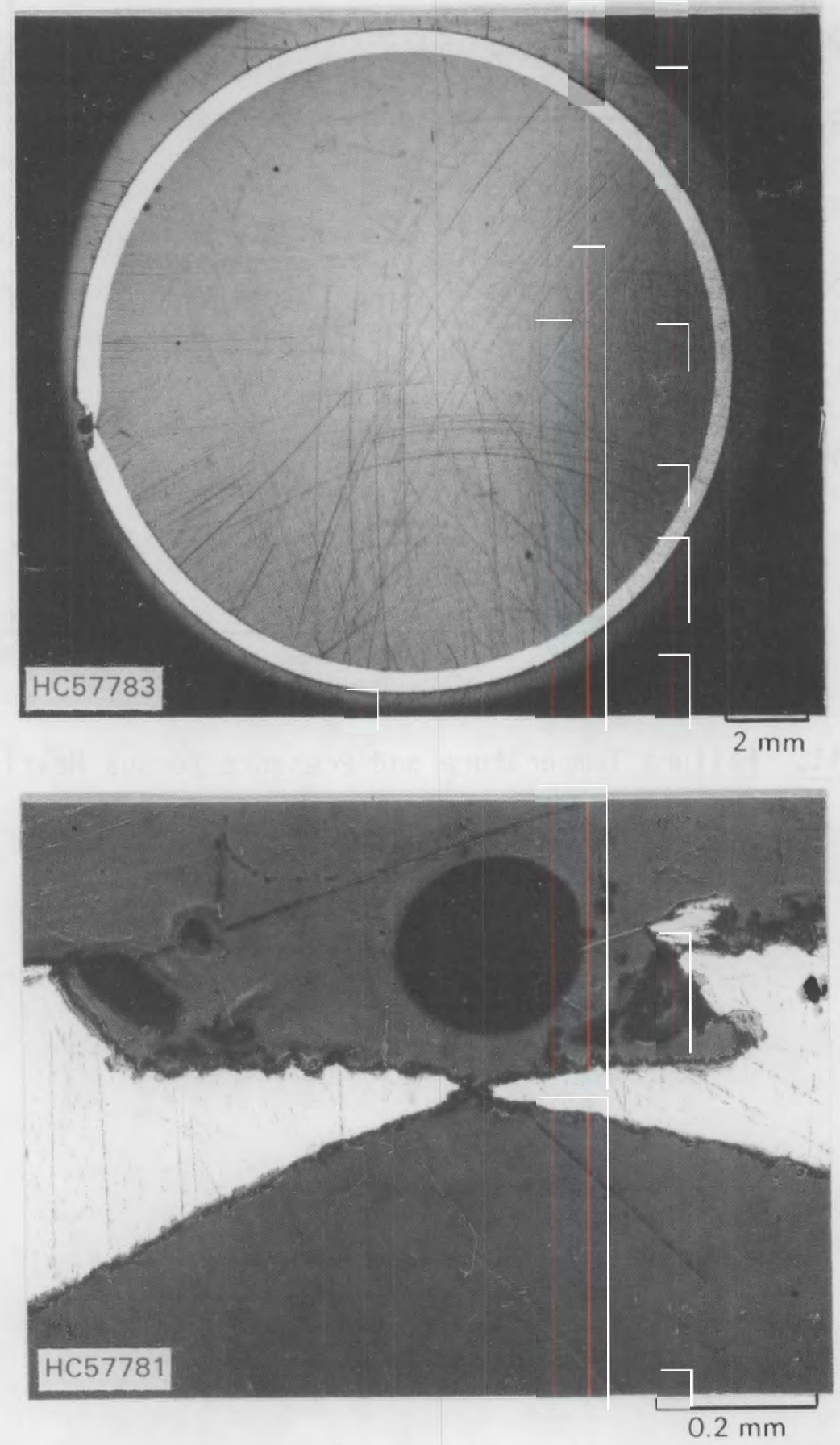

FIGURE 12. Cross-Sectional Views of Failure Location for Rod TP-D04-G9 (without fuel; 28 in. from bottom of rod) 


\section{CONCLUSIONS}

The following conclusions are based on the work presented in this report:

- The maximum rate of temperature rise during a postulated abnormal thermal transient during dry storage was calculated to be $15^{\circ} \mathrm{C} / \mathrm{h}$.

- Because the time required to breach spent fuel cladding after a postulated incident of blocked cooling exceeds 1 week, adequate time would be available for operator response to remove the blockage before a cladding breach could occur.

- The cladding breach resulting from a postulated abnormal heating incident during dry storage is a small pinhole and will not compromise confinement of fuel particles following an incident.

- The ductile cladding breach associated with abnormal heating during dry storage would not propagate breaches in adjacent spent fuel rods. 


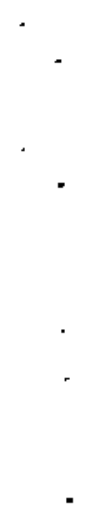




\section{REFERENCES}

Atkin, S. D. 1981. Destructive Examination of 3-Cycle LWR Fuel Rods from Turkey Point Unit 3 for the Climax-Spent fuel Test. HEDL-TME 80-89, Hanford Engineering Development Laboratory, Richland, Washington.

Burian, R. J., et al. 1985. Response of Spent LWR Fuel to Extreme Environments. SAND-85-7213, Sandia National Laboratory, Atbuquerque, New Mexico.

Davis, R. B. 1981. Pretest Nondestructive Examination Data Summary Report on Turkey Point Spent FueT Assemblies D01, 004, and 006 for the Climax-Spent Fuel Test. HEDL-TME 80-83, Hanford Engineering Development Laboratory, Richland, Washington.

Edwards, A. L. 1972. TRUMP--A Computer Program for Transient and Steady-State Temperature Distributions in Multidimensional Systems. UCRL-14754, Rev. 3.

Eggers, P. E. 1982. "Storage and Transportation of Spent Fuel and High-Level Waste Using Only Storage Casks, Spent Fuel Storage Dptions." ANS Topical Meeting, September 27-29, 1982, Savannah Georgia.

Einziger, R. E., and J. A. Cook. 1983. "First Interim Examination of Whole Rod Tests at $230^{\circ} \mathrm{C}$." In Proceedings of the U.S. Nuclear Regulatory Commission Workshop on Spent Fuel/CTadding Reaction During Dry Storage, NUREG/CP-0049, pp. 36-69 and Appendix C.

Einziger, R. E., and R. Koh1i. 1984. "Low-Temperature Rupture Behavior of Zircaloy-Clad Pressurized Water Reactor Spent Fuel Rods Under Dry Storage Conditions." Nucl. Tech. 57:65.

Gilbert, E. R., et al. 1983. "Methodology for Computing Limiting Temperature to Control $\mathrm{UO}_{2}$ Oxidation." ANS Trans. 45:86-87.

Gilbert, E. R., G. D. White, and C. A. Knox. 1985. "Oxidation of U0, at 150 to $350^{\circ} \mathrm{C}$." In Proceedings of the International Workshop on Irradiated Fuel Storage - Operating Experience and Development Programs, October 17-18, 1984, Toronto, Canada.

Guenther, R. J. 1983. Results of Simulated Abnormal Heating Events for FullLength Nuclear Fuel Rods. PNL-4555, Pacific Northwest Laboratory, Richland, washington.

Johnson, A. B., Jr., and E. R. Gilbert. 1983. Technical Basis for Storage of Zircaloy-Clad Spent Fuel in Inert Gases. PNL-4835, Pacific Northwest Laboratory, Richland, Washington.

Lis, J. August 1966. "Experimental Investigation of Natural Convection Heat Transfer in simple and Obstructed Horizontal Annuli." In Proceedings of the Third International Heat Transfer Conference, Chicago, Illinois. 
Lowry, 1. M., et al. 1981. Evaluating Strength and Ductility of Irradiated Zircaloy - Task 5. NUREG/CR-1729, Vol. 1, Battelle Columbus Laboratories, Columbus, Ohio.

Pasupathi, V., and D. Stah1. 1982. Expected Performance of Spent LWR Fuel Under Dry Storage Conditions. EPRI NP-2735, Electric Power Research Institute, Palo Alto, California.

White, G. D., et a1. 1983. "Oxidation of $\mathrm{UO}_{2}$ at $150-350^{\circ} \mathrm{C}$." In Proceedings of the U.S. Nuclear Regulatory Commission horkshop on Spent FueT/CTadding Reaction During Dry Storage, NUREG/C?-0049, pp. 102-110. 
APPENDIX

PRETEST CHARACTERIZATION DATA 
APPENDIX

\section{PRETEST CHARACTERIZATION DATA}

This appendix consists of pretest characterization data on the fuel rod void and gas volumes (Table A.1), the fuel rod fission gas analysis (Table A.2), the hydrogen analysis of the Zircaloy-4 cladding (Table A.3), and the oxide thickness measurements (Table A.4) for the Turkey Point spent fuel rod samples that were used in this study.

TABLE A.1. Fuel Rod Void and Gas Volumes (a)

\begin{tabular}{|c|c|c|c|}
\hline Rod & Void Volume, $\mathrm{cm}^{3}$ & Gas volume, $\mathrm{cm}^{3}$ (STP) & $\begin{array}{c}\text { Pressure at } \\
25^{\circ} \mathrm{C}, \text { psia (MPa) } \\
\end{array}$ \\
\hline D01-G9 & 22.36 & 692.4 & $495.7(3.4)$ \\
\hline $001-G 10$ & 21.01 & 684.2 & $522.6(3.6)$ \\
\hline 001-H9 & 22.05 & 704.6 & $514.2(3.5)$ \\
\hline $004-G 9$ & 22.88 & 711.5 & $498.9(3.4)$ \\
\hline D04-G10 & 22.71 & 717.9 & $507.5(3.5)$ \\
\hline
\end{tabular}

(a) Atkin (1981).

TABLE A.2. Fission Gas Analysis of Fuel Rods(a)

\begin{tabular}{|c|c|c|c|c|c|c|c|}
\hline \multirow[b]{2}{*}{ Rod } & \multicolumn{7}{|c|}{ Gas Analysis, vol\% } \\
\hline & $\mathrm{He}$ & $0_{2}$ & $N_{2}$ & $\mathrm{Ar}$ & $\mathrm{Kr}$ & $\underline{X e}$ & $\mathrm{Xe} / \mathrm{Kr}$ \\
\hline $\mathrm{D} 01-\mathrm{Gg}$ & 99.4 & -- & 0.01 & 0.07 & 0.05 & 0.43 & 8.6 \\
\hline $\mathrm{D} 01-\mathrm{G} 10$ & 99.4 & -- & -- & 0.13 & 0.05 & 0.45 & 9.0 \\
\hline DOl-H9 & 98.7 & - & -- & 0.72 & 0.05 & 0.49 & 9.8 \\
\hline D04-G9 & 98.9 & -- & -- & 0.58 & 0.05 & 0.44 & 8.8 \\
\hline D04-G10 & 98.3 & $0.12^{(b)}$ & $0.43^{(b)}$ & 0.60 & 0.05 & 0.46 & 9.2 \\
\hline
\end{tabular}

(a) Atkin (1981).

(b) $\mathrm{O}_{2}$ and $\mathrm{N}_{2}$ concentrations were due to a small leak in the transfer vial. 
TABLE A.3. Hydrogen Analysis of Zircaloy-4 Cladding(a)

Sample

\begin{tabular}{ll} 
Identification & Hydrogen Content, ppm \\
\hline TP-D01-G9-4 & $39 \pm 13(1 \sigma)$ \\
TP-D01-G9-9 & $56 \pm 6$ \\
TP-D01-G9-14 & $53 \pm 2$ \\
TP-D01-G9-20 & $60 \pm 11$ \\
TP-001-G9-25 & $90 \pm 5$ \\
TP-D01-G9-12 & $82 \pm 3$ \\
TP-D04-G9-8 & $39 \pm 2$ \\
TP-D04-G9-14 & $53 \pm 3$ \\
NBS Standard 352(b) & $33.5 \pm 2.0$
\end{tabular}

(a) Atkin (1981).

(b) The calibrated NBS value is $32 \pm 2 \mathrm{ppm}$. The standard was run at the beginning of the analysis, after every four samples, and at the end of the analysis.

TABLE A.4. Oxide Thickness Measurements $(a, b)$

Sample from Bottom, Oxide Thickness at

\begin{tabular}{|c|c|}
\hline $\begin{array}{c}\text { Sample } \\
\text { Ident ification }\end{array}$ & $\begin{array}{l}\text { from Bottom, } \\
\text { in. }(\mathrm{cm})\end{array}$ \\
\hline TP-001-G9-3 & $15.5(39)$ \\
\hline TP-D01-G9-8 & $50.5(128)$ \\
\hline TP-D01-G9-13 & $65.0\langle 165\rangle$ \\
\hline TP-D01-G9-19 & $90.5(230)$ \\
\hline TP-001-G9-24 & $120.5(306)$ \\
\hline TP-D01-H9-6 & 65.5 (165) \\
\hline TP-D01-H9-11 & $90.5(230)$ \\
\hline $\begin{array}{l}T P-D 01-G 10-3 \\
T P_{-D 04-G 9-3}\end{array}$ & $\begin{array}{ll}65.5 & (165) \\
40 & (101)\end{array}$ \\
\hline $\begin{array}{l}\text { TP-004-G9-7 } \\
\text { TP-D04-G9-13 }\end{array}$ & $\begin{array}{ll}65.5 & (165) \\
90 & (229)\end{array}$ \\
\hline TP-D04-G10-6 & $65.5(165)$ \\
\hline
\end{tabular}

\begin{tabular}{|c|c|c|c|}
\hline $0^{\circ}(\mathrm{c})$ & $90^{\circ}$ & $180^{\circ}$ & $270^{\circ}$ \\
\hline $5.33 \pm 4.57$ & $4.57 \pm 0.76$ & $5.33 \pm 0.51$ & $5.08 \pm 0.25$ \\
\hline $4.83 \pm 0.51$ & $4.57 \pm 0.25$ & $4.57 \pm 0.25$ & $2.79 \pm 1.78$ \\
\hline $4.83 \pm 0.76$ & $4.83 \pm 0.7$ & $6.86 \pm 0.76$ & $5.08 \pm 0.76$ \\
\hline $6.10 \pm 0.76$ & $8.13 \pm 0.51$ & $7.11 \pm 0.76$ & $6.86 \pm 0.51$ \\
\hline $14.73 \pm 0.76$ & $14.73 \pm 2.03$ & $15.75 \pm 1.02$ & $12.95 \pm 0.76$ \\
\hline $5.33 \pm 1.52$ & $5.59 \pm 0.76$ & $4.57 \pm 0.25$ & $6.10 \pm 0.76$ \\
\hline $12.95 \pm 1.52$ & $8.13 \pm 1.52$ & $14.48 \pm 1.02$ & $8.64 \pm 1.02$ \\
\hline $3.81 \pm 1.27$ & $4.83 \pm 0.51$ & $5.33 \pm 0.76$ & $4.83 \pm 0.51$ \\
\hline $4.06 \pm 0.25$ & $4.57 \pm 0.51$ & $4.32 \pm 0.51$ & $4.83 \pm 0.76$ \\
\hline $4.32 \pm 0.25$ & $4.32 \pm 0.51$ & $4.83 \pm 0.25$ & $4.83 \pm 0.51$ \\
\hline $4.83 \pm 0.76$ & $5.59 \pm 1.78$ & $5.59 \pm 1.52$ & $8.13 \pm 1.02$ \\
\hline $4.32 \pm 0.76$ & $4.06 \pm 0.51$ & $4.83 \pm 1.02$ & $5.08 \pm 0.51$ \\
\hline
\end{tabular}

\footnotetext{
(a) Atkin (1981).

(b) The numbers given are the average of five measurements; the standard deviation (10) of the five measurements is included.

(c) Angle of rotation is from "A" face of assembly looking down.
} 


\section{DISTRIBUTION}

No. of

Copies

OFFSITE

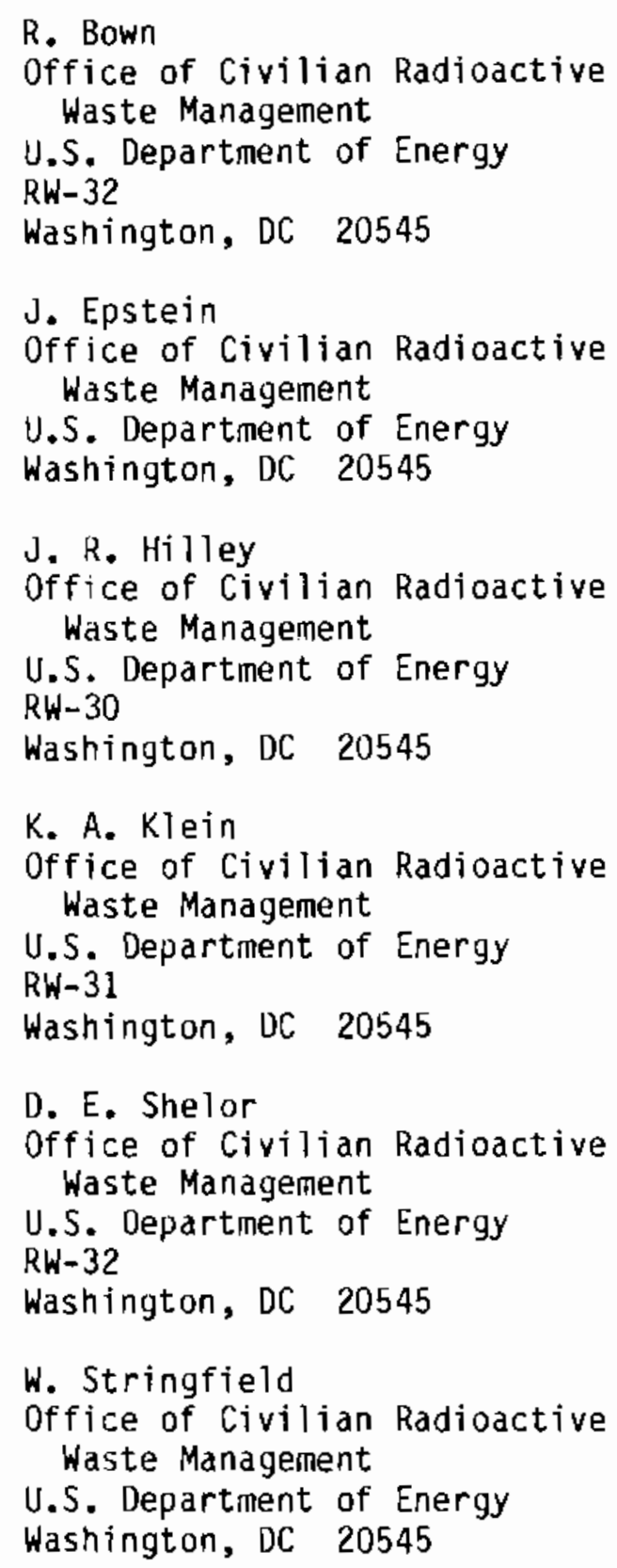

No. of

Copies

J. S. Finucane

Energy Information

Administration

U.S. Department of Energy

$\mathrm{EI}-53$

Washington, DC 20545

K. G. Golliner

U.S. Department of Energy

Albuquerque Operations office

AlDuquerque, NM 87115

C. P. Gertz

U.S. Department of Energy

Idaho Operations office

550 Second Street

Idaho Falls, ID 83401

D. Vieth

U.S. Department of Energy

Nevada Operations office

Las Vegas, NV 89114

C. Matthews

U.S. Department of Energy

Oak Ridge Operations office

P.O. Box E

Oak Ridge, IN 37830

00E Technical Information Center

B. A. Chin

Mechanical Engineering Dept.

247 Wilmore Laboratories

Auburn University, AL 36830

L. A. Walton

Babcock \& Wilcox Co.

P.O. Box 10935

Lynchburg, VA 24506 
No. of

Copies

P. A. File

Baltimore Gas and Electric Co.

Calvert Cliffs Nuclear Power

Plant

Lusby, MO 20657

R. J. Burian

Battelle Columbus Laboratories

505 King Avenue

Columbus, $\mathrm{OH} 43201$

J. A. Carr

Battelle Columbus Laboratories

Office of Nuclear

Waste Isolation

505 King Avenue

Columbus, $\mathrm{OH} 43201$

M. P. Landow

Battelle Columbus Laboratories

$505 \mathrm{King}$ Avenue

Columbus, $0 \mathrm{H} 43201$

V. Pasupathi

Battelle Columbus Laboratories $505 \mathrm{King}$ Avenue

Columbus, $\mathrm{OH} 43201$

D. Stahl

Battelle Columbus Laboratories $505 \mathrm{King}$ Avenue

Columbus, $0 \mathrm{H} 43201$

B. A. Rawles

Battelle Memorial Institute

office of Nuclear Waste Isolation

505 King Avenue

Columbus,. $\mathrm{OH} 43201$

10 T. W. Wood

Battelle Memorial Institute

Washington Operations

2030 M Street-NW

Suite 800

Washington, DC 20036
No. of

Copies

G. A. Townes

BE Inc.

P.0. Box 145

New Ellenton, SC 29809

R. L. Hails

Bechtel Power Corporation

15740 Shady Grove Rd.

Gaithersburg, MD 20760

R. Kunita

Carolina Power \& Light Co.

P.0. Box 1551

Raleigh, NC 27602

G. C. Jobson

Chem-Nuclear Systems, Inc. One Greystone West Building 240 Stoneridge Drive, Suite 100

Columbia, SC 29210

N. Fuhrman

Combustion Engineering, Inc. 1000 Prospect Hill Road

Windsor, CT 06095

R. L. Moscardini

Combustion Engineering, Inc.

1000 Prospect Hill Road

Windsor, CT 06095

G. P. Wagner

Commonwealth Edison

Nuclear Stations Division

P.0. Box 767

Chicago, IL 60690

T. J. Marz

Consumers Power Company

1945 W. Parnall Road

Jackson, MI 49201

S. J. Raffety

Dariland Power Coop.

LaCrosse, WI 54601 
No. of

Copies

R. W. Rasmussen

Duke Power Company

P.O. Box 33189

Charlotte, NC 28242

R. Stanford

Edison Electric Institute

1111 19th St., NW

Washington, OC 2D036

D. H. Schoonen

EG\&G Idaho, Inc.

P.0. Box 1625

Idano Falls, ID 83415

R. F. Willians

Eleztric Power Research Institute

P.0. Box 10412

Palis Alto, CA 94303

R. W. Lambert

Eleitric Power Research Institute

P.0. Box 10412

Palo Alto, CA 94303

G. T. Zamry

Florida Power \& Light Co.

9250 W. Flagler St.

Miami, FL 33174

B. J. Baxter

GA Technologies Inc.

P.0. Box 81608

San Diego, CA 92138

E. E. Voiland

General Electric Co.

Morris Operation

Morris, IL 60450

W. L. Dobson

Gilbert Associates, Inc.

P.0. Box 1498

Reading, PA 19603
No. of

Copies

V. J. Barnhart

GNSI

135 Darling Dr.

Avon, CT 06001

B. Handly

Houston Lighting \& Power Co.

Nuclear Fuels, Baybrook

P.0. Box 1700

Houston, TX 77001

J. A. McBride

E. R. Johnson Associates, Inc.

11702 Bowman Green Drive

Reston, VA 22090

L. M. Trosten

LeBoeuf, Lamb, Leiby, \& MacRae

1333 New Hampshire Ave. NW

Washington, DC 20036

L. D. Ramspott

Lawrence Livermore National Laboratory

P.0. Box 808

Mail Stop L-404

Livermore, CA 94550

V. M. Oversby

Waste Package Task, NNWS I

Lawrence Livermore National Laboratory

P.0. Box 808

Liverinore, CA 94550

G. D. Whittier

Maine Yankee Atomic Power Co.

Edison Drive

Augusta, ME 04336

R. Whale

Michigan Public Service

Commission

6545 Mercantile Way

Lansing, M1 48909 
No. of

Copies

R. Calabro

Northeast Utilities Service Co.

P.0. Box 270

Hartford, CT 06101

R. Isakson

Northeast Utilities Service Co. P.0. Box 270

Hartford, CT 06101

E. Krinick

Northeast Utilities Service Co. P.0. Box 270

Hartford, CT 06101

M. T. Pitek

Northeast Utilities Service Co. P.0. Box 270

Hartford, CT 06101

J. Houston

Nuclear Assurance Corp.

5720 Peachtree Parkway

Norcross, GA 30092

J. M. Viebrock

Nuclear Assurance Corp.

5720 Peachtree Parkway

Norcross, GA 30092

J. Clark

Nuclear Fuel Services

6000 Executive B1vd.

Rockville, MO 20852

R. T. Haelsig

Nuclear Packaging Inc.

1010 S. 336th St.

Federal Way, WA 98003

G. J. Antonucci

NUS Corporation

910 Clopper Rd.

Gaithersburg, MD 20878
No. of

Copies

\author{
J. V. Massey \\ NUTECH Engineers \\ 145 Martinvale Lane \\ San Jose, CA 95119 \\ J. Van Cleve \\ Oak Ridge National Laboratory \\ P.O. Box $X$ \\ Oak Ridge, TN 37831 \\ M. Litterman \\ Pacific Gas \& Electric, \\ Irojan Fuel \\ 121 S.W. Salmon St. \\ Portland, OR 97204 \\ M. L. Picklesimer \\ Pic Products Co. \\ 221 Meadowood Lane \\ Montevello, AL. 35115 \\ Portland General Electric \\ 131 S.W. Salmon Street \\ Portland, OR 97204 \\ G. C. Allen \\ Sandia National Laboratory \\ Transportation Technology Center \\ P.0. Box 5800 \\ Albuquerque, NM 87185 \\ J. F. Ney \\ Sandia National Laboratory \\ Transportation Technology Center \\ P.0. Box 5800 \\ Albuquerque, NM 87185. \\ E. Kuhns \\ Stone and Webster Engineering \\ Corp. \\ 1 Penn Plaza \\ 250 W. 34th St. \\ New York, NY 10119
}


No. of

Copies

H. B. Brooks

Tennessee Valley Authority

404 Krystal Building

Chat tanooga, TN 37401

J. B. Moegling

Tennessee Valley Authority

404 Krystal Building

Chattanooga, TN 37401

E. Gordon

Transnuclear, Inc.

507 Newmark Esplanade

Rockville, MD 20850

J. Mangusi

Transnuclear, Inc.

1 N. Broadway

White Plains, NY 10601

B. R. Teer

Transnuclear, Inc.

1 N. Broadway

White Plains, NY 10601

C. E. King

Uranium Mgt. Corp.

310 DeGuigne Drive

Sunnyvale, CA 94086

T. Cotton

Office of Technology Assessment

U.S. Congress

Washington, DC 20510

N. H. Davison

U.S. Nuclear Regulatory Commission

Office of Nuclear Materials

Safety and Safeguards

Washington, DC 20555
No. of

Copies

\author{
C. Feldman \\ U.S. Nuclear Regulatory \\ Commission \\ Office of Nuclear Regulatory \\ Research \\ Washington, DC 20555 \\ J. Roberts \\ U.S. Nuclear Regulatory \\ Comrnission \\ office of Nuclear Materials \\ Safety and Safeguards \\ Washington, DC 20555 \\ L. C. Rouse \\ U.S. Nuclear Regulatory \\ Commission
}

Spent Fuel Storage Installation

Division of Fuel Cycle and Material Safety

Washington, DC 20555

S. P. Turel

U.S. Nuclear Regulatory Comrnission

Office of Nuclear Regulatory Research

Washington, DC 20555

W. J. Wachter

U.S. Tool and Die, Inc.

4030 Route 8

Allison Park, PA 15101

S. P. Keck

Virginia Electric \& Power

P.0. Box 26666

Richmond, VA 23261

M. L. Smith

Virginia Electric \& Power

P.0. Box 26666

Richmond, VA 23261 
No. of

Copies

J. A. Nevshema]

Westec Services, Inc.

P.0. Box 765

Muscatine, IA 52761-0765

E. A. Bassler

Westinghouse Electric Corp.

Box 2728

Pittsburgh, PA 15230

A. R. Hakl

Westinghouse Electric Corp.

Waste Technology Services Div.

P.0. Box 10864

Pittsburgh, PA 15236

J. B. Wright

Westinghouse Electric Corp.

P.0. Box 708

Mercury, NV 89023

N. Dayem

R. F. Weston Co.

2301 Research Bivd.

Rockville, MD 20850

E. Benz

R. F. Weston Co.

2301 Research Blvd.

Rockville, MD 20850

ONSITE

6 DOE Kichland Operations Dffice

J. P. Collins

R. D. Izatt (4)

D. C. Langstaff
No. of

Copies

2 Hanford Engineering Development Laboratory

R. E. Einziger

R. L. Knecht

Rockwell Hanford Company

C. L. Brown

62 Pacific Northwest Laboratory

M. J. Apted

W. J. Bailey

G. H. Beeman (10)

B. M. Cole

J. M. Creer

S. K. Edler

M. D. Freshley

E. R. Gilbert (20)

R. J. Guenther

R. J. Hall

P. E. Hart

J. N. Holloway

A. B. Johnson, Jr. (5)

C. A. Knox

D. K. Kreid

M. R. Kreiter

J. L. McElroy

G. L. McVay

L. G. Morgan

D. F. Newman

D. R. Oden

J.T.A. Roberts

K. J. Schneider

Publishing Coordination (2)

Technical Information (5) 